TFBP-TR-276

for U.S. Nuclear Regulatory Commission

\title{
REACTIVITY INITIATED ACCIDENT TEST SERIES \\ TEST RIA 1-2 \\ EXPERIMENT OPERATING SPECIFICATION
}

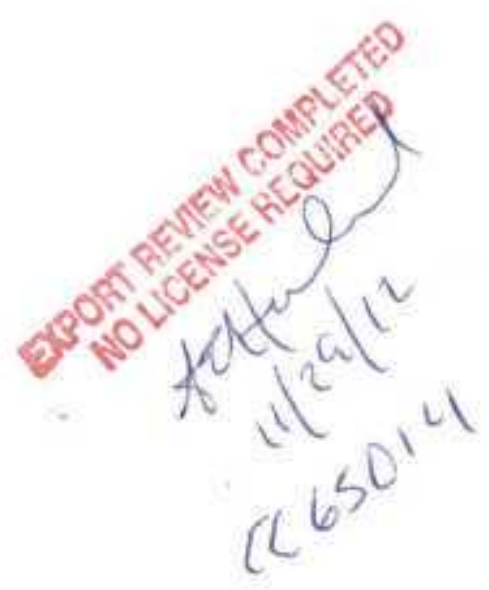

July 1978

EG\&G Idaho, Inc.

IDAHO NATIONAL ENGINEERING LABORATORY

\section{DEPARTMENT OF ENERGY}

IDAHO OPERATIONS OFFICE UNDER CONTRACT EY-76-C-07-1570

PDF Available

Commm 
TFBP-TR-276

for U.S. Nuclear Regulatory Commission

\section{REACTIVITY INITIATED ACCIDENT TEST SERIES TEST RIA 1-2 EXPERIMENT OPERATING SPECIFICATION}

July 1978

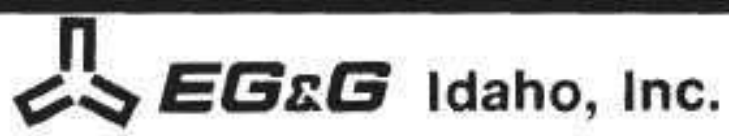

IDAHO NATIONAL ENGINEERING LABORATORY

\section{DEPARTMENT OF ENERGY}


, 
TFBP-TR-276

August 1978

Rev. -0-

\section{REACTIVITY INITIATED ACCIDENT TEST SERIES}

TEST RIA 1-2

\section{EXPERIMENT OPERATING SPECIFICATION}

Z. R. Martinson

R. S. Semken

Approved:
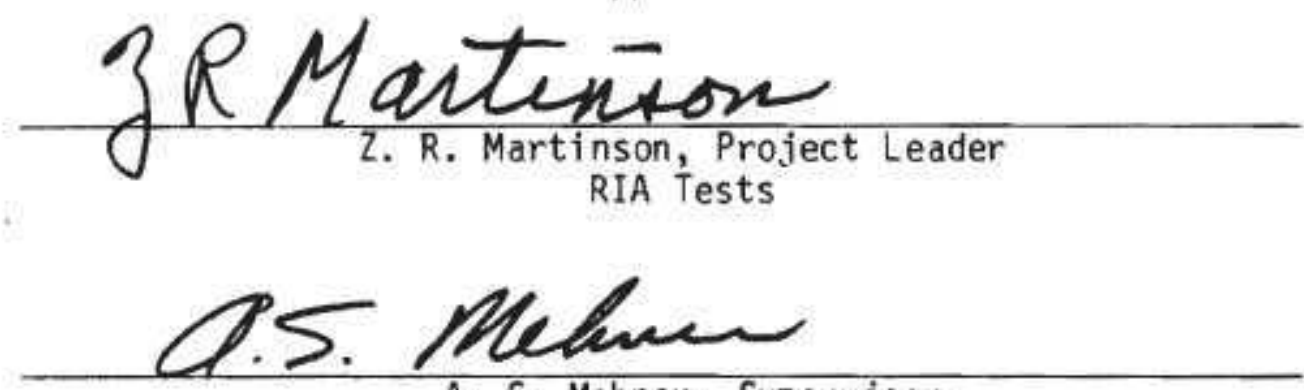

\section{A. S. Mehner, Supervisor}

RIA, PCM, IE and Gap Conductance Tests Section

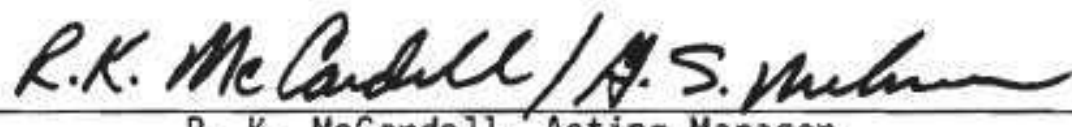

R. K. McCarde 11, Acting Manager

Experiment Specification and Analysis Branch

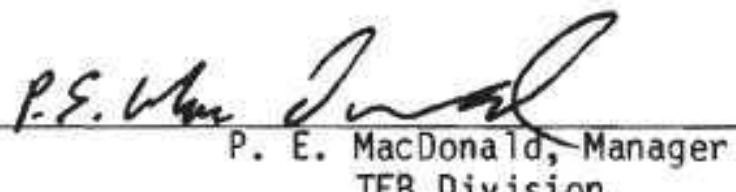

THERMAL FUELS BEHAVIOR PROGRAM

EG\&G IDAHO, INC. 



\section{REACTIVITY INITIATED ACCIDENT TEST SERIES \\ TEST RIA 1-2 \\ EXPERIMENT OPERATING SPECIFICATION}

August 1978 


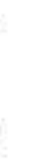


CONTENTS

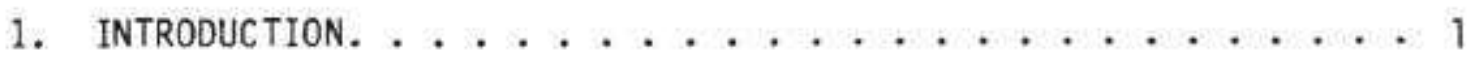

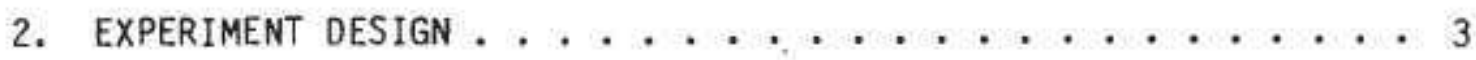

2.1 Fuel Rods. .................. 3

2.2 Flow Shrouds................... 3

2.3 Test Assembly................. 3

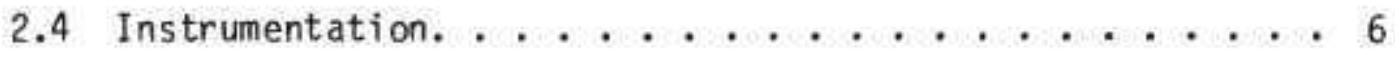

2.4.1 Fuel Rod Instrumentation .......... 6

2.4.2 Test Assembly Instrumentation. . . . . . . . 9

2.4.3 Plant Instrumentation.......... 11

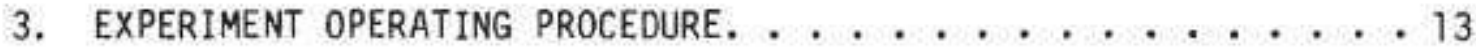

3.1 Instrument Status Checks and Minimum Operable

Instrumentation. ............ 13

3.2 Heat Up Phase. . . . . . . . . . . 18

3.3 Prenuclear Instrument Drift Recording. . . . . . . . . 19

3.4 Fuel Rod Power Calibration and Conditioning. . . . . . 19

3.5 Loop Heatup Prior to Transient Testing . . . . . . , 20

3.6 Power Transient Testing.............. . 20

4. DATA ACQUISITION AND REDUCTION REQUIREMENTS . . . . . . . 23

4.1 Data Acquisition Requirements. . . . . . . . . 23

4.2 Data Reduction Requirements. . . . . . . . . . . 27

4.2.1 Quick Look Report................. 27

4.2.2 Experiment Data Report .............229

4.2.3 Test Results Report. ............ 29

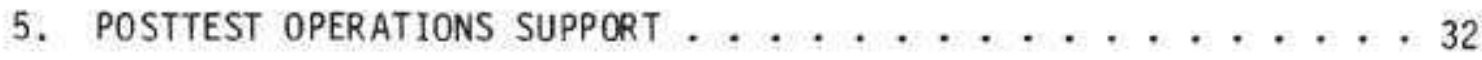

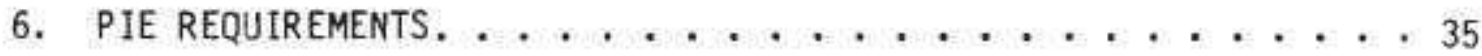

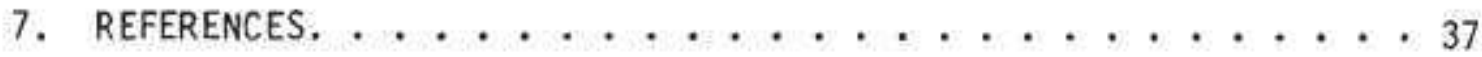

APPENDIX A STATUS CHECK LISTS FOR INSTRUMENTATION. . . . . . . . A-1 


\section{FIGURES}

1. Fue 1 rod arrangement in four-rod hardware for Test RIA 1-2. . 7

2. Strip chart set-up for RIA 1-2 power calibration conditioning, and transient phases.......... 26

\section{TABLES}

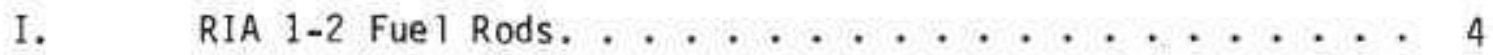

II. RIA 1-2 Fuel Rod Design Characteristics. . . . . . . 5

III. Fue I Rod Instrumentation for Test RIA 1-2. . . . . . 8

IV. Test Train Instrumentation for Test RIA $1-2 \ldots \ldots$

V. Test RIA $1-2$ Coolant Conditions. ............ 14

VI. Minimum Required Operable Instrumentation During

Various Phases of Test RIA 1-2......... 15

VII. RIA 1-2 Instrument Status Check-0perable Instrument

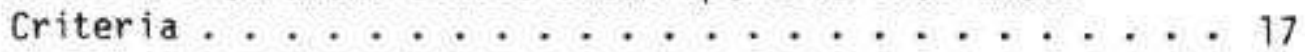

VIII. Operating Conditions During Power Calibration and

Conditioning Phases of Test RIA 1-2......... . 21

IX. Test RIA 1-2 PBF/DARS Instrument Identification, Data Channel Recording, and Display Requirements. . . . . . 24

X. Plots for RIA 1-2 Quick Look Report. . . . . . . . . 28

XI. Plots for RIA 1-2 Test Results Report-Power

Calibration and Conditioning Phases. . . . . . . . 30

XII. Plots for RIA 1-2 Test Results Report-Transient

Phase. ................. 31

XIII. Radiological Parameters Applicable to One Test RIA 1-2

Rod After PBF Testing. ............ 33 


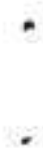

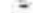

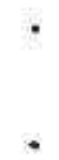




\section{INTRODUCTION}

This document describes the experiment operating specifications for the Reactivity Initiated Accident (RIA) Test RIA 1-2 to be conducted in the Power Burst Facility (PBF) at the Idaho National Engineering Laboratory. The experiment requirements and objectives for the RIA tests are described in the RIA Experiment Requirements Document (ERD) ${ }^{[1]}$ while the experiment specifications are described in the RIA 1-2 Experiment Specification Document (ESD) [2]. The RIA Series I research objectives are to determine fuel failure thresholds, modes and consequences as functions of enthalpy insertion, irradiation history, and fuel design. Coolant conditions of pressure, temperature, and flow rate that are typical of hot-startup conditions in commercial boiling water reactors (BWRs) will be used.

The second test in Series I, Test RIA 1-2, will be comprised of four individual rods, each surrounded by a separate flow shroud. The four rods will be preirradiated. The specific objectives of the test are to: (1) characterize the response of preirradiated fuel rods during a RIA event conducted at BWR hot-startup conditions and (2) evaluate the effect of internal rod pressure on preirradiated fuel rod transient response.

The test sequence will begin with steady state power operation to condition the fuel (pellet cracking and relocation) and determine the fuel rod power calibration. The loop will then be cooled down, the test train removed from the in-pile tube, and the cobalt flux wires that are mounted on each flow shroud will be replaced. The transient fuel rod energy deposition for the Test RIA 1-2 rods will be chosen from the fue 1 rod response vs. energy deposition observed in the first three phases of the RIA Scoping Test and the first test of Series 1, Test RIA 1-1.

Section 2, which follows, describes the design of the test fue 1 rods, test assembly, and instrumentation associated with Test RIA 1-2. Section 3 describes the planned experiment conduct for the 
test. The data recording and reduction requirements are provided in Sections 4 and 5 . Sections 6 and 7 describe the posttest operations support and the postirradiation examination requirements associated with Test RIA 1-2. 


\section{EXPERIMENT DESIGN}

Test RIA 1-2 is comprised of four independently shrouded fuel rods which are installed in a support structure termed the test assembly. The non-instrumented high pressure spool pieces will be installed in the loop piping. This section describes the design of the fuel rods, flow shrouds, test assembly, and instrumentation associated with each component of the test train.

\subsection{Fuel Rods}

The fue 1 rods consist of four MAPI rods previously irradiated to burnups of about $4800 \mathrm{MWd} / \mathrm{t}$ in the Saxton Reactor. The irradiated rods are designated as $802-1,802-2,802-3$, and $802-4$. A fifth irradiated MAPI Rod 802-5 will serve as a backup for the test rods. The designation and burnup of the fuel rods are given in Table I. The as-fabricated nominal design characteristics of these fuel rods are given in Table II.

After it is instrumented, Rod $802-1$ will be backfilled with $77.7 \%$ helium and $22.3 \%$ argon to a pressure of $0.103 \mathrm{MPa}$. This gas mixture simulates the thermal conductivity of fill gases, including fission gases in the Saxton MAPI fuel rods. Rods 802-3 and 802-5 will not be opened prior to testing. Rods $802-2$ and $802-4$ will be backfilled with the $77.7-22.3 \%$ mixture of helium and argon to a pressure of $2.41 \mathrm{MPa}$.

\subsection{Flow Shrouds}

Individual zircaloy-4 flow shrouds, having a nominal inner diameter of $16.30 \mathrm{~mm}$ and an outer diameter of $22.6 \mathrm{~mm}$, surround each rod. An orifice plate with a $6.95 \pm 0.025 \mathrm{~mm}$ diameter hole is located below each shroud.

\subsection{Test Assembly}

The Battelle Pacific Northwest Laboratory four-rod test train will be used for Test RIA 1-2. In the test train, the fuel rods are 
TABLE I

RIA 1-2 FUEL RODS

\begin{tabular}{ccc}
\hline $\begin{array}{c}\text { PBF RIA } \\
\text { TEST ROD NUMBER }\end{array}$ & $\begin{array}{c}\text { AVERAGE } \\
\text { BURNUP (MWd/t) }\end{array}$ \\
\hline $802-1$ & ORIGINAL WESTINGHOUSE NUMBER & 5220 \\
$802-?$ & MAPI M-? & 5110 \\
$802-3$ & MAPI M-13 & 4430 \\
$802-4$ & MAPI M-59 & 4430 \\
$802-5$ & MAPI M-69 & 4530 \\
& MAPI M-8 & \\
\hline
\end{tabular}


TABLE II

TEST RIA 1-2 FUEL ROD DESIGN CHARACTERISTICS

\section{Characteristic}

Fue 1

Material

Pellet 00

Pellet Length

Pellet Enrichment

Density

Fuel Stack Length

End Configuration

\section{Cladding}

Material

Tube OD

Tube Wall Thickness

Yield Strength

Ultimate Strength

Fuel Rod

Gas Plenum Length

Insulator Pellets

\section{MAPI [a]}

$\mathrm{UO}_{2}$

$8.59 \mathrm{~mm}$

$15.2 \mathrm{~mm}$

$5.7 \%$

94\% TD

$0.914 \mathrm{~m}$

dished

Zircaloy 4

$9.99 \mathrm{~mm}$

0.572 mr minimum

$570 \mathrm{MPa}$

$700 \mathrm{MPa}$

$45.7 \mathrm{~mm}$

None

[a] Data are preirradiation values. 
held rigidly at the top, with the rods free to expand axially downward. The location of each fuel rod and associated flow shroud is shown in Figure 1.

\subsection{Instrumentation}

The instrumentation for this test is designed to aid in determining fuel rod response characteristics and failure mechanisms during an RIA transient.

2.4.1 Fuel Rod Instrumentation. Table III summarizes the fuel rod instrumentation including information as to description, range, response time, and signal conditioning.

Rod 802-1 will be instrumented for measurement of the internal gas pressure, cladding surface temperature, and cladding elongation. Rod 802-2 will be instrumented for measurement of the internal gas pressure, cladding surface temperature, plenum temperature, and cladding elongation. Rods $802-3$ and $802-5$ will be instrumented for cladding elongation, and Rod 802-4 will be instrumented for measurement of the internal gas pressure and cladding elongation.

The following gives the specification of the fuel rod instrumentation:

(1) Two Type S, titanium sheathed cladding surface thermocouples with spaded junctions will be installed on each of Rods $802-1$ and Rod $802-2$. The thermocouples will be welded to the cladding outer surface. The location of each thermocouple above the bottom of the fuel stack and their azimuthal orientation are shown in Table III.

(2) A 6.9 MPa Kaman pressure transducer will be mounted on Rod 802-1, and a $17.2 \mathrm{MPa}$ Kaman pressure transducer will be mounted on Rods 802-2 and 802-4 to measure rod internal pressure in the upper plenum. 


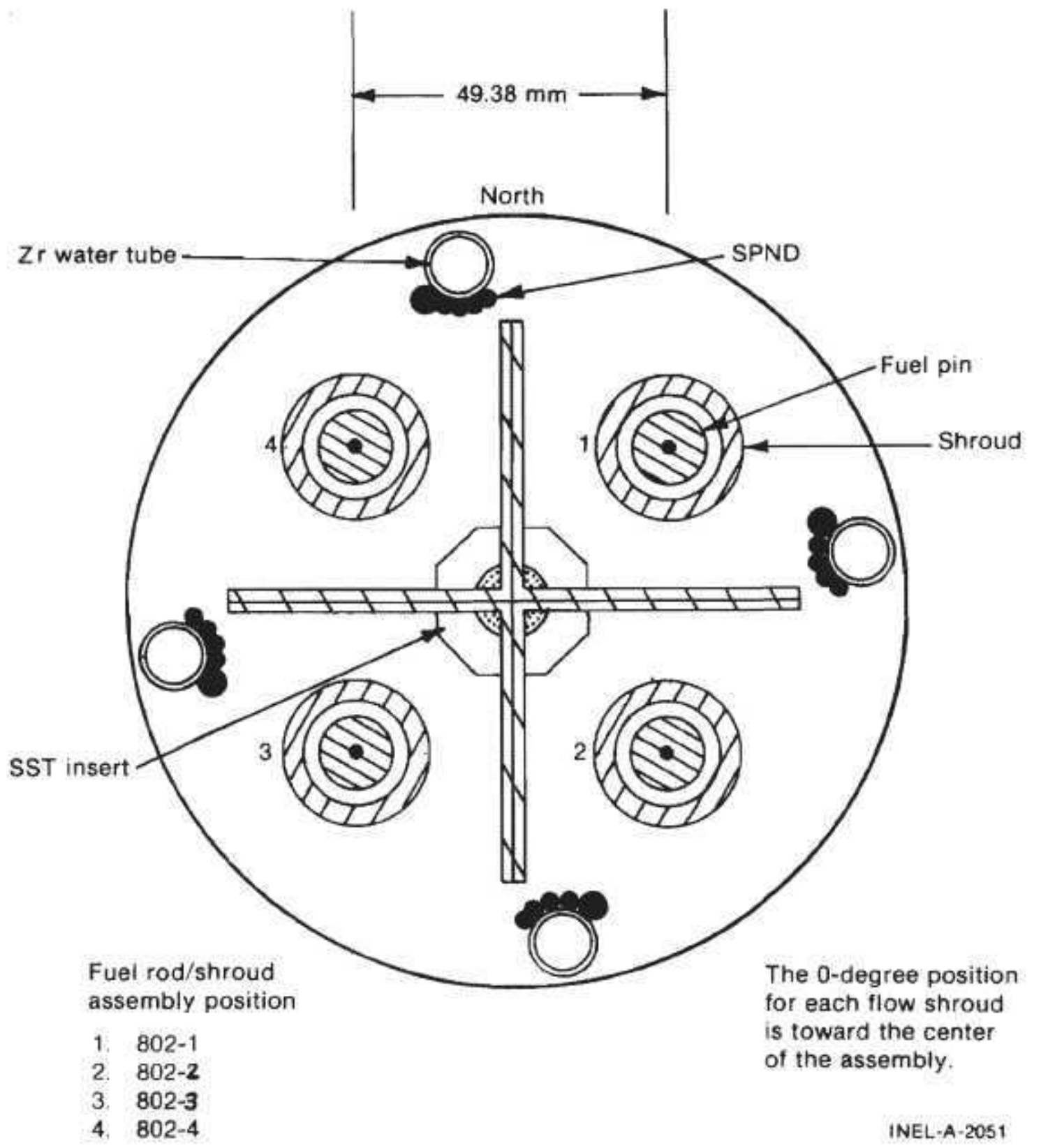

Fig. 1 Fuel rod arrangement of four-rod hardware for Test RIA $1-2$ 
TABLE III

FUEL ROD INSTRUMENTATION FOR TEST RIA 1-2

\begin{tabular}{|c|c|c|c|c|c|c|}
\hline Measurement & Instrument & $\begin{array}{l}\text { Instrument } \\
\text { Location }\end{array}$ & $\begin{array}{l}\text { Fue 1 Rod } \\
\text { to be } \\
\text { Instrumented }\end{array}$ & Instrument Range & $\begin{array}{l}\text { Requested } \\
\text { Maximum } \\
\text { Response } \\
\text { Time (s) } \\
\end{array}$ & $\begin{array}{l}\text { Number and Type } \\
\text { of Instruments } \\
\end{array}$ \\
\hline $\begin{array}{l}\text { Rod internal } \\
\text { pressure }\end{array}$ & $\begin{array}{l}\text { Pressure } \\
\text { Transducer }\end{array}$ & Upper Plenum & $802-1$ & 0 to $6.9 \mathrm{MPa}$ & 0.002 & $\begin{array}{l}\text { Kaman pressure } \\
\text { transducer }\end{array}$ \\
\hline $\begin{array}{l}\text { Rod internal } \\
\text { pressure }\end{array}$ & $\begin{array}{l}\text { Pressure } \\
\text { Transducer }\end{array}$ & Upper Plenum & $802-2,802-4$ & 0 to $17 \mathrm{MPa}$ & 0.002 & $\begin{array}{l}\text { Kaman pressure } \\
\text { transducer }\end{array}$ \\
\hline $\begin{array}{l}\text { Cladding } \\
\text { surface tem- } \\
\text { perature }\end{array}$ & Therrnocouple & $\begin{array}{l}46 \mathrm{~cm} \text { frcm } \\
\text { bottom of } \\
\text { fue } 1 \text { stack at } \\
0^{\circ} \text { orienta- } \\
\text { tion, and } \\
79 \mathrm{~cm} \text { from } \\
\text { bottom of } \\
\text { fue } 1 \text { stack } \\
\text { at iso } \\
\text { orientation }\end{array}$ & $802-1,802-2$ & 500 to $2150 \mathrm{~K}$ & 0.01 & $\begin{array}{l}\text { Two Type } 5 \text { thermo- } \\
\text { couples per rod }\end{array}$ \\
\hline $\begin{array}{l}\text { Plenum } \\
\text { temperature }\end{array}$ & Thermocouple & Upper Plenum & $802-2$ & 300 to $1000 \mathrm{~K}$ & 0.02 & $\begin{array}{l}\text { One Type K thermo- } \\
\text { couple }\end{array}$ \\
\hline
\end{tabular}


(3) A plenum thermocouple (Type K) will be located at the centerline of the spring in the plenum region of Rod 802-2 to measure the plenum gas temperature.

The remaining rods (Rods $802-3$ and $802-5$ ) will not be instrumented except for measurement of the cladding elongation.

2.4.2 Test Assembly Instrumentation. Table IV summarizes the test assembly instrumentation including information as to description, range, response time, and signal conditioning. The test assembly instrumentation consists of the following:

(1) Three coolant pressure transducers (a $69 \mathrm{MPa} E \mathrm{E} \&$, a 17.2 MPa Kaman, and a 17.2 MPa Schaevitz) located above the flow shroud outlet to measure the transient pressure response and normal system pressure.

(2) Four Kaman pressure transducers located above the flow shroud outlets to measure individual flow shroud transient pressure pulses generated by fuel rod failure.

(3) A turbine flowneter, located at the inlet of each flow shroud, to measure the experiment coolant flow.

(4) A pair of Chrome1-Alumel (Type K) thermocouples (one located at the inlet and the other at the outlet of each flow shroud) to measure the temperature $r$ ise in the coolant.

(5) A Chrome1-Alumel (Type K) thermocouple mounted at the in let of each flow shroud to measure the coolant inlet temperature.

(6) A Chromel-Alumel (Type K) thermocouple mounted at the outlet of each flow shroud to measure the coolant outlet temperature. 
TEST TRAIN INSTRUMENTATION FOR TEST RIA $1-2$

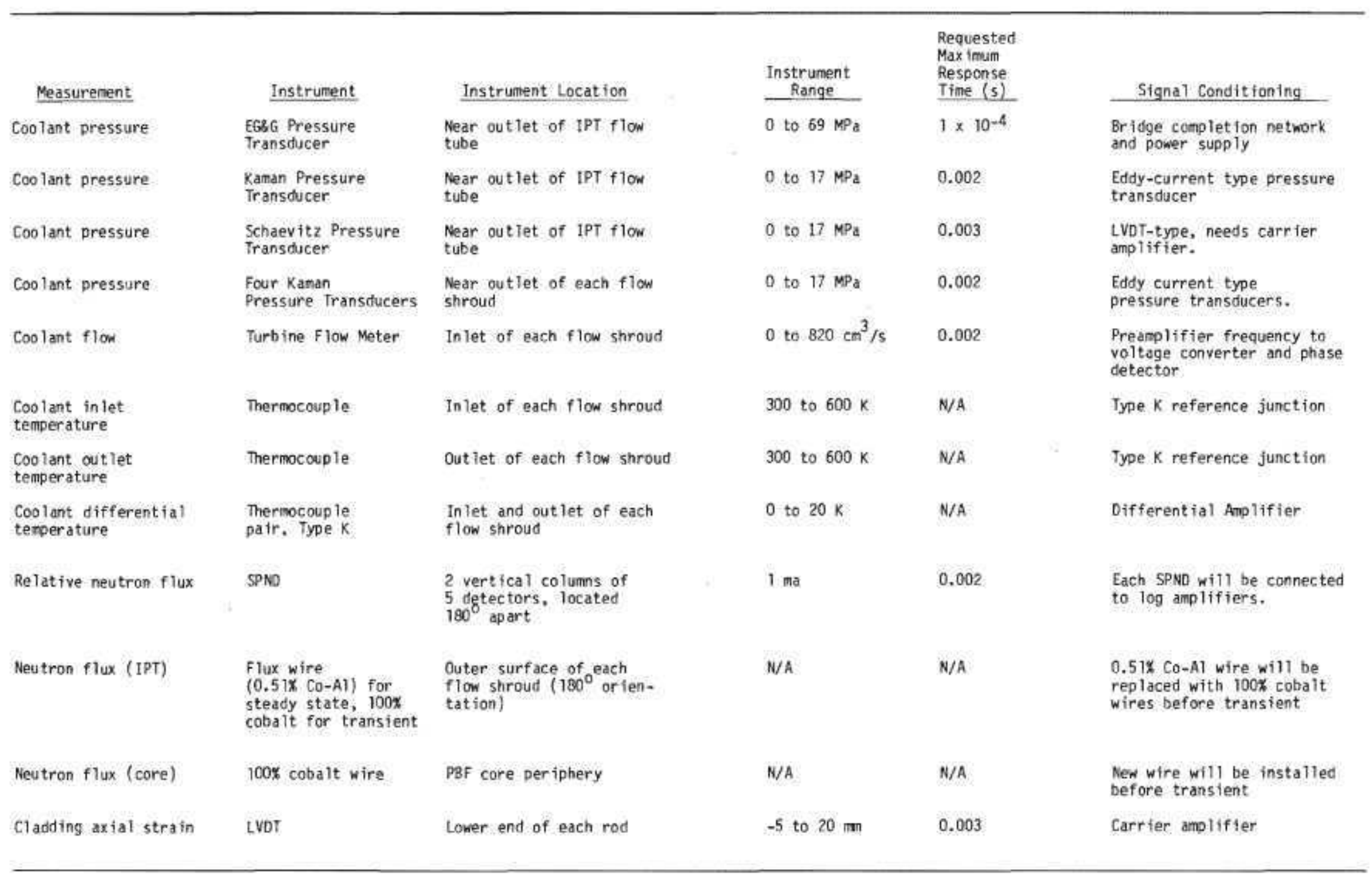


(7) A linear variable differential transformer (LVDT) mounted below the lower end of each fuel rod to measure the cladding axial elongation.

(8) A flux wire mounted on the outer surface of each flow shroud at the 180-degree orientation to measure the integrated neutron flux. Flux wires with $0.51 \%$ cobalt and $99.49 \%$ aluminum content will be used during the power calibration and conditioning phases. These wires will be removed and replaced with $100 \%$ cobalt wires before the transient power burst.

(9) Ten (10) self-powered neutron detectors (SPND) located in two vertical columns 180 degrees apart to measure the relative neutron flux.

2.4.3 Plant Instrumentation. Plant instrument data to be recorded along with the test train instrument data are as follows:

(1) NMS-3 ion chamber

(2) PPS-1, PPS-2, PPS-3, PPS -4 ion chambers

(3) TR-1, TR-2 ion chambers

(4) EV-1, EV-2 ion chambers

(5) In-pile tube system pressure

(6) In-pile tube " $\Delta p "$

(7) Loop flow rate

(8) Loop fission product detection system

(9) Core fuel rod LVDTs (3) 
(10) Reactor vessel strain gauges (3)

(11) Loop pressure transducers (9)

In addition, a (0.51\% cobalt-99.49\% aluminum) flux wire will be installed in the reflector region of the core for the power calibration and preconditioning. A $100 \%$ cobalt flux wire will be installed before the power burst. The digital readout for the Heise loop pressure gauge should be available for monitoring from the PBF control room. If it is not, a closed circuit television camera will be positioned to view the Heise loop pressure gauge, and the image will be displayed on the television monitor at the PBF control room. 


\section{EXPERIMENT OPERATING PROCEDURE}

Details of the experimental procedure of Test RIA 1-2 are discussed in the following sections. Test RIA 1-2 will be conducted in three primary test phases preceded by the nonnuclear heat-up and interspaced with a number of instrumentation status checks. Coolant conditions for each phase of the test are given in Table V. Each experiment operating phase and the instrumentation status requirements are considered individually below.

\subsection{Instrument Status Checks and Minimum Operable Instrumentation}

To monitor the experiment status and to meet test objectives requires that certain fuel rod and test assembly instrumentation be operable throughout the experiment or during specific phases of the experiment. The loss of a critical instrument or a critical combination of instruments needed for a current or subsequent test phase will require the test procedures to be suspended. Since instrument status will be monitored on the PBF/DARS display, the source of instrument output difficulties can range from instrument malfunction or failure to signal conditioning, transmission or DARS calibration problems. If the experiment is interrupted by an apparent instrumentation malfunction, it will be necessary for cognizant data system and instrumentation personnel to determine the source and potential remedies for the malfunction indication. When possible, remedial actions will be completed and the test procedures continued. If it is determined that the instrument has failed or that repairs can be made only by removing the test train from the reactor, test procedures will remain suspended. This experiment status will be maintained pending a decision by the RIA Project Leader, TFBD Management, and Directorate management as to the course of action to be followed.

Critical instrumentation for Test RIA $1-2$ have been defined in terms of minimum operable instrumentation for various times during the test sequence. Table VI presents this information. Instrument status checks are planned before and during the test to ensure conformity to 
TABLE V

TEST RIA 1-2 COOLANT CONDITIONS

\begin{tabular}{lccc}
\hline $\begin{array}{l}\text { Test } \\
\text { Phase }\end{array}$ & $\begin{array}{c}\text { Coolant Inlet } \\
\text { Temperature }(\mathrm{K})\end{array}$ & $\begin{array}{c}\text { System } \\
\text { Pressure }(\mathrm{MPa})\end{array}$ & $\begin{array}{c}\text { Shroud Coolant } \\
\text { Flow Rate } \\
\left(\mathrm{cm}^{3} / \mathrm{s}\right)\end{array}$ \\
\cline { 2 - 3 } $\begin{array}{l}\text { Prenuclear } \\
\begin{array}{l}\text { Power Cali- } \\
\text { bration }\end{array}\end{array}$ & $538 \pm 1$ & $6.45 \pm 0.14$ & $760 \pm 15$ \\
$\begin{array}{l}\text { Conditioning } \\
\text { Transient Testing }\end{array}$ & $538 \pm 1$ & $6.45 \pm 0.14$ & $760 \pm 15$ \\
\end{tabular}


TABLE VI

MINTMUN REOUIREO OPERABLE INSTRUMENTATION DEIRING VARIOUS PHASES OF TEST RIA 1-2

\begin{tabular}{|c|c|c|c|c|c|}
\hline TWSTRUMENTATION & m. & $\begin{array}{l}\text { PRE-INSTALLATION } \\
\text { OF TEST } \\
\text { TRAIN IN } \\
\text { IPT }\end{array}$ & $\begin{array}{l}\text { DURING } \\
\text { HERT-UP }\end{array}$ & $\begin{array}{l}\text { PRE- } \\
\text { PQUER } \\
\text { CALIBAATION } \\
\text { PHESE }\end{array}$ & $\begin{array}{l}\text { PRE- } \\
\text { TRANSTENT } \\
\text { PHASE }\end{array}$ \\
\hline $\begin{array}{l}17 \mathrm{MPa} \text { Strouit Pressure } \\
\text { Transducers }\end{array}$ & (4) & 4 of 4 Rea $d$ & 3 of 4 Req 'd & 3 of 4 Req'd & 3 of 4 Req'd \\
\hline $\begin{array}{l}\text { Cladd ing Thermo- } \\
\text { couples }\end{array}$ & (2) & 2 of 2 Reg'd & is of $2 \operatorname{Req} d$ & I of 2 Req'd & 1 of 2 Req'd \\
\hline Pfenum Theraocaup Tes & $(t)$ & Req'is & Nat Req'd & Not Rena'd & Not Reg'd \\
\hline $\begin{array}{l}\text { Interna } 1 \text { Pressure } \\
\text { Yransducers }\end{array}$ & (3) & 3 of 3 fleq'd & 2 of 3 Req'd & 2 of 3 Req" $d$ & 2 of 3 Req'd \\
\hline $\begin{array}{l}69 \mathrm{MPa} \text { Coolant Pressur't } \\
\text { Transducers }\end{array}$ & (1) & Rea "if & Req 'd & Pea'd & Reg'd \\
\hline $\begin{array}{l}17 \mathrm{MPa} \text { coolant Pressure } \\
\text { Transducers }\end{array}$ & (2) & 1 of $2 \operatorname{Rea} 2 d$ & 1 of 2 Peq ${ }^{+} d$ & 1 of 2 Req'd & I of 2 Reg'd. \\
\hline $\begin{array}{l}\text { Fue I Rod Coolant } \\
\text { Flowneters }\end{array}$ & (4) & 4 of 4 Rea if & 4 of 4 Req 's & 3 of 4 Req'd & 2 of $\triangle$ Req'd \\
\hline Clatding L VVTs & (4) & 4 of 4 Rea'd & 3. of $48 \mathrm{Req} d$ & 2. of 4 Req 'd & 2 of 4 Reg'd \\
\hline $\begin{array}{l}\text { Coolant inlet } \\
\text { Therancouples }\end{array}$ & (4) & 4 of 4 Reg $d$ & 2 of $\angle \operatorname{Req}{ }^{\prime} d$ & 1 of 4 Req 'd & 1 of 4 Req'd \\
\hline $\begin{array}{l}\text { Coolant Dutlet } \\
\text { Thernocouples }\end{array}$ & (4) & 4 of 4 Rea'd & 2 of 4 rea'd & 1 of 4 Req'of & not Rea'd: \\
\hline $\begin{array}{l}\text { Coolant Different ial } \\
\text { Thernocouples }\end{array}$ & (4) & 4 of 4 Reo'd & 4 of $4 \operatorname{Req} d \mathrm{~d}$ & $\triangle$ of $A$ Req'o & hot Ree'd \\
\hline SPNOS & $\begin{array}{l}\text { (2) Ougdrants } \\
\text { of } 5 \text { esch) }\end{array}$ & $\begin{array}{l}\text { 2. of } 2 \text { Quadrants } \\
\text { Req'd }\end{array}$ & $\begin{array}{l}2 \text { of } 2 \\
\text { Quadrants } \\
\text { Req'd }\end{array}$ & $\begin{array}{l}1 \text { of } 2 \\
\text { Qudrants } \\
\text { Reg'd }\end{array}$ & $\begin{array}{l}\text { I of } 2 \\
\text { Ouadrants } \\
\text { ReQ'it }\end{array}$ \\
\hline $\begin{array}{l}\text { Core Transient lon } \\
\text { Chambers rapable of } \\
\text { Monitor ing. Expected } \\
\text { Peak Power }\end{array}$ & Not Peq ${ }^{2} d$ & Not Reg'd & $\begin{array}{l}3 \text { of e ither } \\
\text { EV-1, EV }-2 \text {, } \\
T R-1 \text { and } \\
\text { Th-2, or } \\
\text { Equivalent } \\
\text { Req'd }\end{array}$ & $\begin{array}{l}3 \text { of either: } \\
\text { EV-?, EV-2 } \\
\text { 3R-1 and } \\
\text { RR-2, or } \\
\text { Equivalent } \\
\text { ReQ's }\end{array}$ & $\begin{array}{l}3 \text { of eltiter } \\
\text { EV-1, EV-2, TR-1, } \\
\text { and TR-2, or } \\
\text { eduivalent Req'd }\end{array}$ \\
\hline
\end{tabular}


the requirements in Table VI. Instrument status checks will occur at the TRA assembly area and again in the reactor building prior to loading the test train in the in-pile tube (IPT). Each fuel rod and test assemb ly transducer will be checked according to the Instrument Checkout Procedures documented in TP-RIA-1201 and TP-RIA-1202. Any quality discrepancy reports issued as a result of TP-RIA-1201 and TP-RIA-1202 must be signed off by the RIA Project Leader or his alternate.

The remaining status checks are to be made at isothermal conditions during each heat-up of the IPT system, prior to the power calibration phase, and prior to the transient power burst. Table VII lists the operating conditions and the acceptance criteria for each instrument of the test. The acceptable operation criteria appear in the table as ranges of measured values in SI units. The ranges stipulated are based on the listed operating conditions and expected accuracies of the instruments used. Appendix A contains check lists, consistent with Table VII, that are to be incorporated in the Experiment Operating Procedures. Certification that each instrument is within range must be made by the supervisor of the Instrumentation and Data Section 4 or his alternate. If an instrument is not functioning the failure must be certified by the supervisor of the Test Train Fabrication Section or his alternate. For all cases where the instruments are not within range the RIA Project Leader's or his alternate's approval must be obtained in order to continue the test procedures. Any deviation from the acceptance criteria will be cause for further instrument checkout and corrective action taken where possible. Criteria deviations must be cross-checked against the minimum operable instrumentation list presented in Table VI and appropriate actions taken where necessary. The last status check will be performed just before the power burst.

Prior to any data acquisition, the PBF/DARS output will be verified by inputting voltages to the low level amplifiers or in accordance with a checklist to be supplied by the Instrument and Data systems Section. This checklist will be incorporated in the 
TABLE VII

TEST RIA 1-2 INSTRUMENT STATUS CHECK-OPERABLE INSTRUMENT CRITERIA

\begin{tabular}{|c|c|c|c|}
\hline & During Heatup & Before Power Calibration & Before Transient \\
\hline $\begin{array}{l}\text { Loop Temperature }(\mathrm{K}) \\
\text { Loop Pressure }(\mathrm{MPa}) \\
\text { Flow Through Shrouds }\left(\mathrm{cm}^{3} / \mathrm{s}\right)\end{array}$ & $\begin{array}{l}450 \pm 0 \\
3.45 \pm .14 \\
500 \pm 15\end{array}$ & $\begin{array}{l}538 \pm 1 \\
6.45 \pm 0.14 \\
760 \pm 15\end{array}$ & $\begin{array}{l}538 \pm 1 \\
6.45 \pm 0.14 \\
85 \pm 5\end{array}$ \\
\hline INSTRUMENT & & ACCEPTABLE RANGE & \\
\hline \multicolumn{4}{|l|}{ Fuel Rod Instrument } \\
\hline $\begin{array}{l}\text { Fue } 1 \text { Rod } 802-1 \\
\text { Interna } 1 \text { Pressure } \\
\text { Cladding T/Cs (2) }\end{array}$ & $\begin{array}{l}0.0 \text { to } 1.0 \mathrm{MPa} \\
430 \text { to } 470 \mathrm{~K}\end{array}$ & $\begin{array}{l}0 \text { to } 1.0 \mathrm{MPa} \\
522 \text { to } 544 \mathrm{~K}\end{array}$ & $\begin{array}{l}0 \text { to } 1.0 \mathrm{MPa} \\
522 \text { to } 554 \mathrm{~K}\end{array}$ \\
\hline $\begin{array}{l}\text { Fuel Rod } 802-2 \\
\text { Internal Pressure } \\
\mathrm{Cl} \text { add ing } \mathrm{T} / \mathrm{Cs}(2) \\
\text { Plenum TC }\end{array}$ & $\begin{array}{l}2.5 \text { to } 3.5 \mathrm{MPa} \\
430 \text { to } 470 \mathrm{~K} \\
430 \text { to } 470 \mathrm{~K}\end{array}$ & $\begin{array}{l}3.3 \text { to } 3.8 \mathrm{MPa} \\
522 \text { to } 554 \mathrm{~K} \\
522 \text { to } 554 \mathrm{~K}\end{array}$ & $\begin{array}{l}3.3 \text { to } 3.8 \mathrm{MPa} \\
522 \text { to } 554 \mathrm{~K} \\
522 \text { to } 554 \mathrm{~K}\end{array}$ \\
\hline $\begin{array}{l}\text { Fuel Rod } 802-4 \\
\text { Internal Pressure }\end{array}$ & 2.5 to $3.5 \mathrm{MPa}$ & 3.3 to $3.8 \mathrm{MPa}$ & 3.3 to $3.8 \mathrm{MPa}$ \\
\hline \multicolumn{4}{|l|}{ Test Train Instrumentation } \\
\hline $\begin{array}{l}\text { Flow Shroud Turbine Flowmeters (4) } \\
\text { Coolant Inlet T/Cs (4) } \\
\text { Coolant Outlet T/Cs (4) } \\
\text { Coolant } \triangle T C \text { Pairs (4) } \\
17.2 \mathrm{MPa} \text { Shroud Pressure Trans- } \\
\text { ducers (4) } \\
17.2 \mathrm{MPa} \text { Pressure Transducer (2) } \\
69 \mathrm{MPa} \text { Pressure Transducer (1) } \\
\text { Neutron Detector (10) } \\
\text { LVDT (4) }\end{array}$ & $\begin{array}{l}485 \text { to } 515 \mathrm{~cm}^{3} / \mathrm{s} \\
440 \text { to } 460 \mathrm{~K} \\
440 \text { to } 460 \mathrm{~K} \\
-1.6 \text { to } 1.6 \mathrm{~K} \\
\pm 1 \mathrm{MPa} \text { of Heise } \\
\pm 1 \mathrm{MPa} \text { of Heise } \\
\pm 3.5 \mathrm{MPa} 8 \mathrm{f} \mathrm{Heise} \\
\pm \mathrm{IR}>10^{8} \Omega \\
-6.4 \text { to }-3.8 \mathrm{~mm}\end{array}$ & $\begin{array}{l}745 \text { to } 775 \mathrm{~cm}^{3} / \mathrm{s} \\
528 \text { to } 548 \mathrm{~K} \\
528 \text { to } 548 \mathrm{~K} \\
-1.6 \text { to } 1.6 \mathrm{~K} \\
\pm 1 \mathrm{MPa} \text { of Heise Gauge } \\
\pm 1 \mathrm{MPa} \text { of Heise Gauge } \\
\pm 3.5 \mathrm{MPa} \text { of Heise Gaug } \\
\text { IR }>10^{8} \\
-6.2 \text { to }-3.6 \mathrm{~mm}\end{array}$ & $\begin{array}{l}80 \text { to } 90 \mathrm{~cm}^{3} / \mathrm{s} \\
528 \text { to } 548 \mathrm{~K} \\
528 \text { to } 548 \mathrm{~K} \\
\text { Not Required } \\
\pm 1 \mathrm{MPa} \text { of Heise Gauge } \\
+1 \mathrm{MPa} \text { of Heise Gauge } \\
\pm \quad 3.5 \mathrm{MPa} \text { of Heise Gauge } \\
\text { IR }>10^{8} \Omega \\
-6.2 \text { to } 3.6 \mathrm{~mm}\end{array}$ \\
\hline
\end{tabular}


Experiment Operating Procedures and will be signed off by the supervisor of the Instrumentation and Data section or his alternate prior to loop heatup.

In the event of a DARS channel failure, permission must be obtained from the Supervisor of the Instrumentation and Data Section or his alternate before the failed channel can be changed. If any channels are changed subsequent to the DARS verification, then the changed channels must be reverified. In addition, any channels being doubly recorded on the surveillance system channel electronics cannot be changed after verification. A posttest integrated data systems calibration will be performed after reactor building re-entry is permitted.

\subsection{Loop Heatup Prior to Power Calibration}

The initial part of testing will consist of a hydrostatic pressure check, followed by heatup of the loop to the desired coolant temperature, pressure, and flow, which are: $538 \pm 1 \mathrm{~K}, 6.45 \pm 0.14$ $\mathrm{MPa}$, and $760 \pm 15 \mathrm{~cm}^{3} / \mathrm{s}$ flow through each flow shroud, respectively. Instrument status checks will be made during heatup and again after the loop coolant temperature has increased to $538 \mathrm{~K}$. If possible, the IPT flow bypass $w i l l$ be measured at $538 \mathrm{~K}$ by closing the flow bypass line valve and then measuring the flow through the four flow shrouds and the total loop flow. Care should be taken not to exceed the $820 \mathrm{~cm}^{3} / \mathrm{s}$ flow capability of the shroud flowmeters. The flow bypass value will then be opened to verify that an experiment flow of $85 \mathrm{~cm}^{3} / \mathrm{s}$ can be obtained at $538 \pm 1 \mathrm{~K}$ and $6.45 \pm 0.14 \mathrm{MPa}$.

Data will be recorded on the DARS during the hydrostatic pressure check, the heatup, and the flow checks. 


\subsection{Prenuclear Instrument Drift Recording}

Data channels shall be recorded for at least 30 minutes to establish any instrument drift rates. This recording should be done after heat-up and prior to nuclear operation at stable system conditions of: $538+1 \mathrm{~K}$ inlet temperature, $6.45 \pm 0.14 \mathrm{MPa}$ IPT pressure, and $760 \pm 15 \mathrm{~cm}^{3} / \mathrm{s}$ flow through each flow shroud.

\subsection{Fuel Rod Power Calibration and Conditioning}

The objectives of the power calibration and conditioning phases of the test are to intercalibrate the thermal-hydraulically determined fuel rod power with reactor power and the self-powered neutron detectors (SPNDs) mounted on the test assembly and to achieve some additional pellet cracking and fuel restructuring of the irradiated Saxton fuel rods. The on-line power calibration will be accomplished by measuring the coolant pressure, coolant inlet temperature, coolant temperature rise, and experiment flow for each rod. An axial peak-toaverage neutron flux ratio of 1.35 will be used for preliminary calculations. The required coolant conditions during these phases are: $538 \pm 1.0 \mathrm{~K}$ inlet temperature, $6.45 \pm 0.14 \mathrm{MPa}$ IPT pressure, and $760 \pm 15 \mathrm{~cm}^{3} / \mathrm{s}$ flow through each shroud. The anticipated PBF operation during these phases is sumarized in Table VIII. Power calibration data will be recorded for about five minutes at each power level. The maximum ramp rate (increase or decrease) in fuel rod power should not exceed $1 \mathrm{~kW} / \mathrm{m}$ per minute.

A temporary Channel 3 reactor shutdown is required that will shut down the reactor if any of the cladding surface thermocouples on Rods $802-1$ or 802-2 indicate a temperature exceeding $700 \mathrm{~K}$. The shutdown circuit will include a time delay of 2 seconds to eliminate shutdown from noise spikes. This circuit will be removed or made inoperable prior to running the power transient. 
After completion of the fuel rod power calibration and conditioning phases, the loop will be cooled down, the test train removed from the IPT, and the flux wires mounted on the flow shrouds will be removed and replaced with $100 \%$ cobalt flux wires. The $0.51 \%$ cobalt99.49\% aluminum flux wire installed in the core will be replaced with an $100 \%$ cobalt flux wire.

\subsection{Loop Heatup Prior to Transient Testing}

Instrument status checks will be made before heatup and again before performing the power transient burst. IPT loop operating conditions required for the power transient will be: $538 \pm 1.0 \mathrm{~K}$ in let temperature, $6.45 \pm 0.14 \mathrm{MPa}$ IPT pressure, and $85 \pm 5 \mathrm{~cm}^{3} / \mathrm{s}$ flow through each experiment flow shroud. The test train flowmeters will be intercalibrated with the total loop flow by increasing the experiment coolant flow to a maximum and then decreasing the flow to a minimum at $538 \mathrm{~K}$. Data will be recorded during the hydrostatic pressure check during the flow calibration, and during heatup. Reactor primary coolant conditions will be nominally $15000 \mathrm{gpm}$ flow, 297 $\pm 3 \mathrm{~K}$ inlet temperature, and atmospheric pressure for the power burst.

\subsection{Power Transient Testing}

The reactor period for the transient test will be chosen on the basis of the PBF lead rod tests, the RIA Scoping Test, Test RIA 1-1, and the Test RIA 1-2 power calibration results. The Channel 3 reactor shutdown circuit will be made inoperable prior to running this transient.

The following sequence of operations leading to the initiation of a power transient burst is designed to minimize the steady state energy before the transient. It is essential that the steady state contribution of the flux wire activation be a small percentage of the power transient activation. 


\section{TABLE VIII}

OPERATING CONDITIONS DURING POWER CALIBRATION AND CONDITIONING PHASES OF TEST RIA $1-2$

\begin{tabular}{|c|c|c|c|}
\hline $\begin{array}{l}\text { Expected } \\
\text { Time } \\
\text { Duration [a] } \\
\text { (minute) }\end{array}$ & $\begin{array}{l}\text { Peak Fuel Rod } \\
\text { Power [b] } \\
(\mathrm{kW} / \mathrm{m})\end{array}$ & $\begin{array}{l}\text { Anticipated } \\
\text { Reactor Power } \\
\text { (MW) } \\
\end{array}$ & $\begin{array}{l}\text { Expected } \\
\text { Temperature } \\
\text { Rise of IPT } \\
\text { Flow (K) }\end{array}$ \\
\hline 30 & 0 to 13 & 0 to 7.6 & \\
\hline 5 & 13 & 7.6 & 2.9 \\
\hline 7 & 13 to 20 & 7.6 to 11.8 & \\
\hline 5 & 20 & 11.8 & 4.5 \\
\hline 6 & 20 to 26 & 11.8 to 15.3 & \\
\hline 5 & 26 & 15.3 & 5.9 \\
\hline 6 & 26 to 32 & 15.3 to 18.8 & \\
\hline 5 & 32 & 18.8 & 7.2 \\
\hline 6 & 32 to 38 & 18.8 to 22.3 & \\
\hline 5 & 38 & 22.3 & 8.6 \\
\hline 6 & 38 to 44 & 22.3 to 25.9 & \\
\hline 5 & 44 & 25.9 & 10.10 \\
\hline 6 & 44 to 48 & 25.9 to 28 & \\
\hline 180 & 48 & 28 & 10.9 \\
\hline 47 & 48 to 3 & to 1.8 & \\
\hline 10 & 3 & 1.8 & 0.7 \\
\hline 41 & 3 to 44 & 1.8 to 25.9 & \\
\hline 180 & 44 & 25.9 & 10.0 \\
\hline 41 & 44 to 3 & 25.9 to 1.8 & \\
\hline 10 & 3 & 1.8 & 0.7 \\
\hline 35 & 3 to 38 & 1.8 to 22.2 & \\
\hline 180 & 38 & 22.2 & 8.6 \\
\hline 35 & 38 to 3 & 22.2 to 1.8 & \\
\hline 10 & 3 & 1.8 & 0.7 \\
\hline 29 & 3 to 32 & 1.8 to 18.8 & \\
\hline 180 & 32 & 18.8 & 7.2 \\
\hline 6 & 32 to 26 & 18.8 to 15.3 & \\
\hline 5 & 26 & 15.3 & 5.9 \\
\hline 6 & 26 to 20 & 14.3 to 11.8 & \\
\hline 5 & 20 & 11.8 & 4.5 \\
\hline 7 & 20 to 13 & 11.8 to 7.5 & \\
\hline 5 & 13 & 7.6 & 2.9 \\
\hline 13 & 13 to 0 & 7.6 to 0 & \\
\hline
\end{tabular}

[a] 18 hours and 52 minutes total time.

[b] Reactor power will be increased to $27.8 \mathrm{MW}$ if measured fuel rod peak power does not exceed $52 \mathrm{~kW} / \mathrm{m}$. 
(1) The reactor will be made critical at about $100 \mathrm{~W}$ for determination of the low power critical position of the control rods.

(2) From this position the control rods will be withdrawn an amount required to establish a reactor transient period of approximately 10 seconds. The reactor power will be allowed to increase until the "chamber operable light" indicates that the chambers are functioning properly. Immediately upon reaching this level, the control rods will be inserted an amount required to make the reactor subcritical causing the power to rapidly decrease. Allow no more than $50 \%$ power overshoot above the chamber operable set point in the event a chamber is not functioning properiy.

(3) The transient rods will then be drawn into the core to a position representative of the reactivity insertion required for the reactor transient.

(4) The control rods will then be withdrawn to make the reactor critical at about $100 \mathrm{~W}$. The reactivity inserted by the withdrawal of the control rods and the worth of the transient rods will be compared to ensure the increment of control rod withdrawal determined for the reactor transient is not grossly in error.

(5) The transient rods will then be fully inserted in the core with the control rod position adjusted to the required increment of withdrawal determined for the desired reactivity insertion.

(6) The transient will be initiated manually. The control rod shutdown time or power trip level will be the same as that used previously in the RIA test series for approximately the same reactor transient period. 


\section{DATA ACQUISITION AND REDUCTION REQUIREMENTS}

Instrumentation displays in the PBF Data Acquisition and Reduction System (PBF/DARS) will identify the fuel rod, test assembly, and plant instruments according to the identifiers in Table IX. Prior to each nuclear operation, it shall be verified that data are being recorded and that data are retrievable.

\subsection{Data Acquisition Requirements}

The data channels should be set to record the data based on the requirements of Table IX. Those instruments requiring high frequency recording will be set up to record on the DARS wide band channels or the $E$ \& A system. Those channels on the wide band recorders should also be recorded on the narrow bands. All of the narrow band DARS channels should be available for display on the Vector General. All those instruments which are designated as minimum operable instrumentation for the pre-transient phase of Test RIA 1-2 (Table VI) will be recorded on at least two independent systems of equivalent frequency response to insure against the loss of data in the event that one system becomes inoperable. The surveillance system is an acceptable backup system for the high frequency systems. The PBF/DARS will record data during the cold hydrostatic pressure check, the flow calibration, the heatup phases, during all nuclear operation, and be left on until the loop has been depressurized after the transient. The Surveillance System (SS) need not record data during heatup and 30 minutes after test termination unless requested by the TFBD ES\&A representative. The wide band DARS and E\&A System need not be turned on except for 2 minutes before and 28 minutes after the transient power burst. Figure 2 indicates the data channels which will be required to be displayed on the strip charts during power calibration and fuel conditioning and the transient phase. The display and recording requirements are subject to change at the discretion of the TFBD representative in case of instrument failure or unusual test behavior. The core neutron chamber ranges shown in Table IX are preliminary and should be set according to the expected peak power of the test. The upper range should be set to cover the peak power. 
TABLE IX

TEST RIA 1-2 INSTRUMENT TDENTIFICATION, DATA LHANREL REDOROTKE, AND OTSPLAY REOUIREMENTS

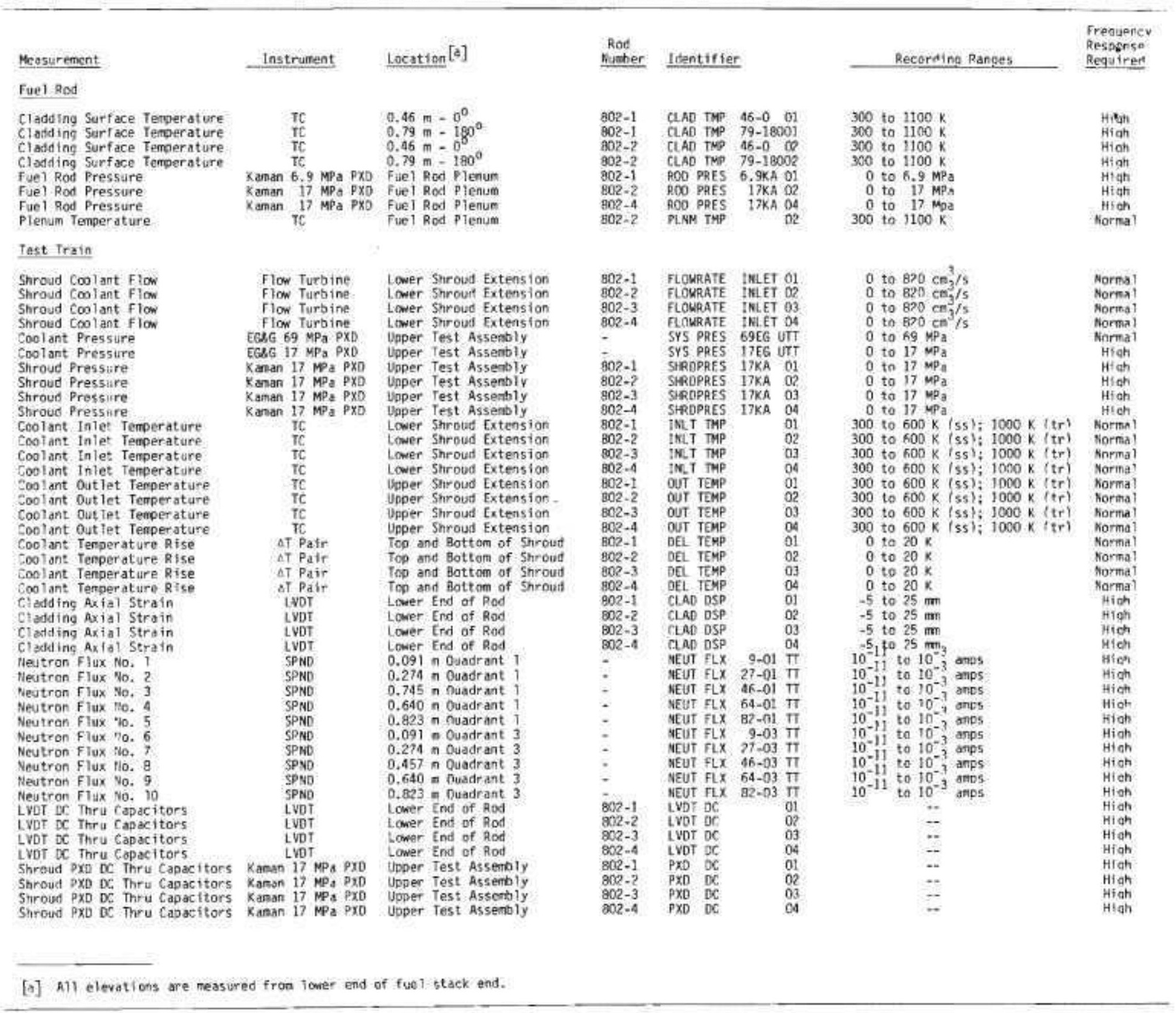


TABLE IX (Continued)

TEST RIA 1-2 INSTRUMEAT IDENTIFICATION, DATA CHANNEL RECORDING, AND DISPLAY REOUIREMENTS

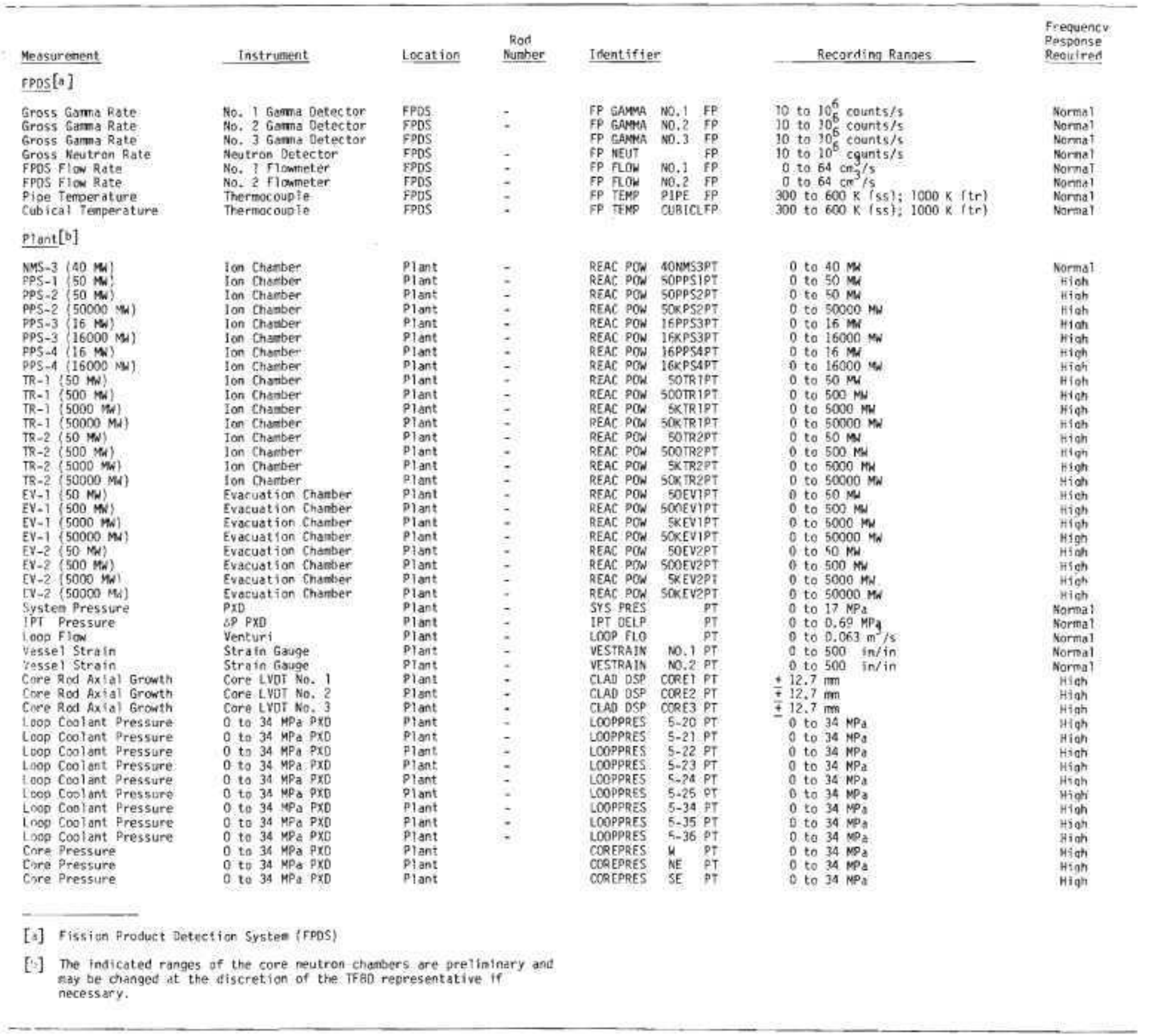



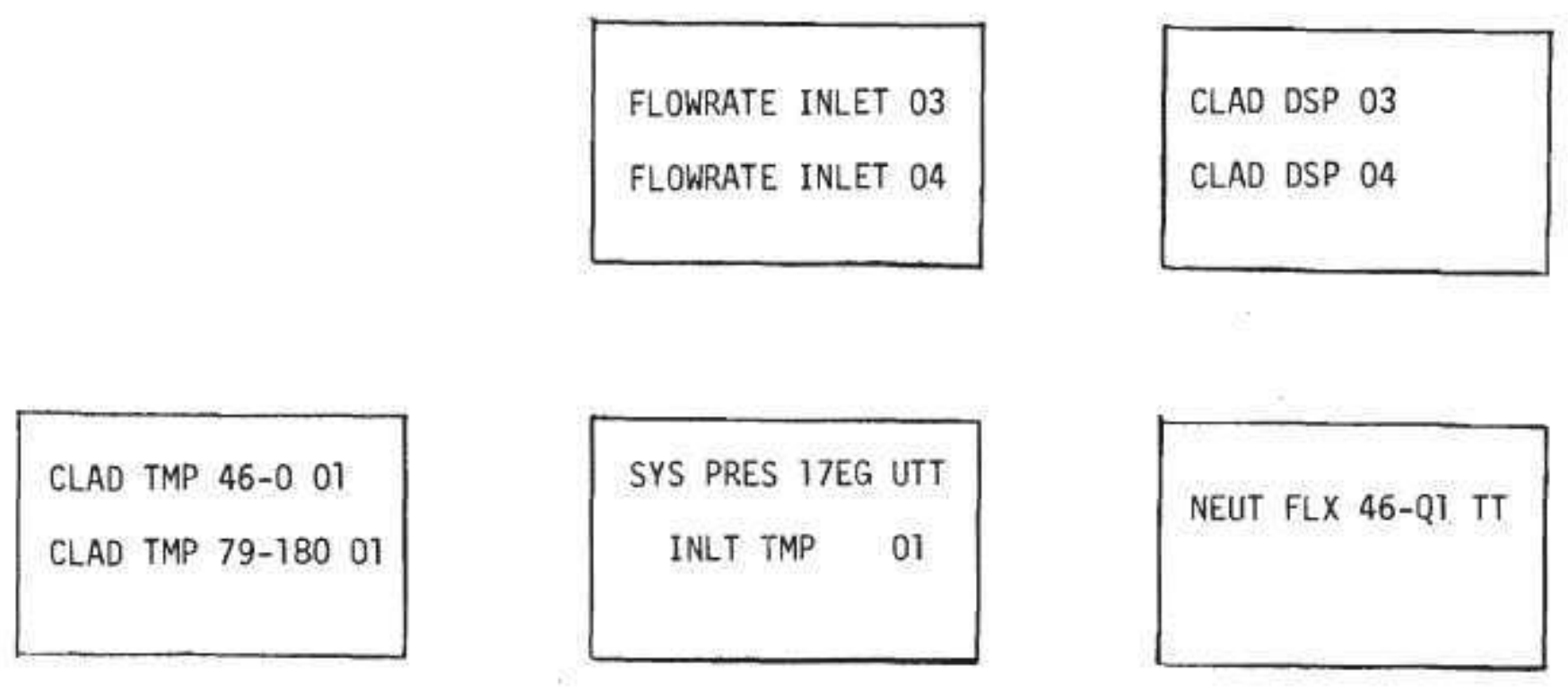

\begin{tabular}{l} 
CLAD TMP 46-0 02 \\
CLAD TMP 79-180 02 \\
\hline
\end{tabular}

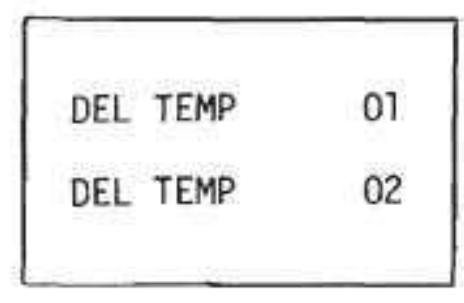

FP GAMMA NO. 1

FP GAMMA No. 2
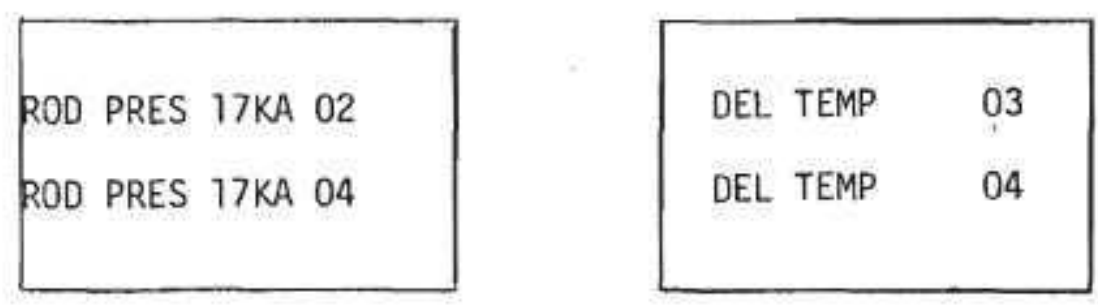

FP GAMMA NO. 3

FP NEUT FP

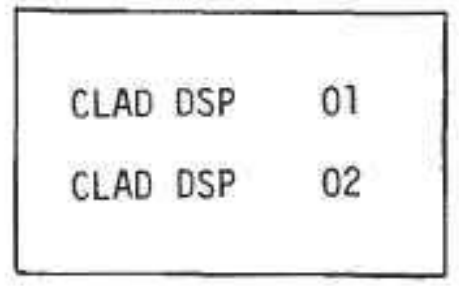

SYS PRES PT

IPT DELP PT

FLOWRATE INLET 02

Fig. 2 Strip chart set-up for RIA 1-2 power calibration, conditioning, and transient phases. 


\subsection{Data Reduction Requirements}

Data reduction and plotting requirements are separated into three segments below. The first segment concerns data reduction and plot requirements needed for the preparation of the RIA 1-2 Quick Look Report. The second concerns data reduction and presentation requirements for the Experimental Data Report and the third for the Test Results Report. Additional plotting requirements will be stipulated for the test analysis, based on test performance and posttest code analyses.

4.2.1 Quick Look Report. Test Data plots and data pretest calculation comparison plots for the Quick Look Report are to be prepared within 72 hours of the completion of the test. Due to the short time allocated for preparation of this document, it is mandatory that this requirement be met. The Quick Look Report will only contain plots of data from the transient portion of the test. That portion of the SPORT computer program required to compute reactor energy and reactivity as a function of time from the power history will be programed into the PBF/DARS computer and the data processed through the program.

The plots generated will go directly into the Quick Look Report without redrawing or handling by graphics personnel. The plots size should conform to $8-1 / 2 \times 11$-inch paper with conventional margins. All plotted data are to be in standard SI units.

Table $X$ lists the plots that are required for the Quick Look Report. Comparison plots showing FRAP-T calculations and corresponding data as a function of time are included. The FRAP-T calculations were previously performed and the output tapes are avallable for data system personne 1 use.

Digital printout of all the data from the reactor neutron detecting chambers (EV-1, EV-2, TR-1 and TR-2) and the SPNDs during the transient will be required. The logarithmic amplifiers for the SPNDS 
TABLE X

PLOTS FOR RIA 1-2 QUICK LOOK REPORT

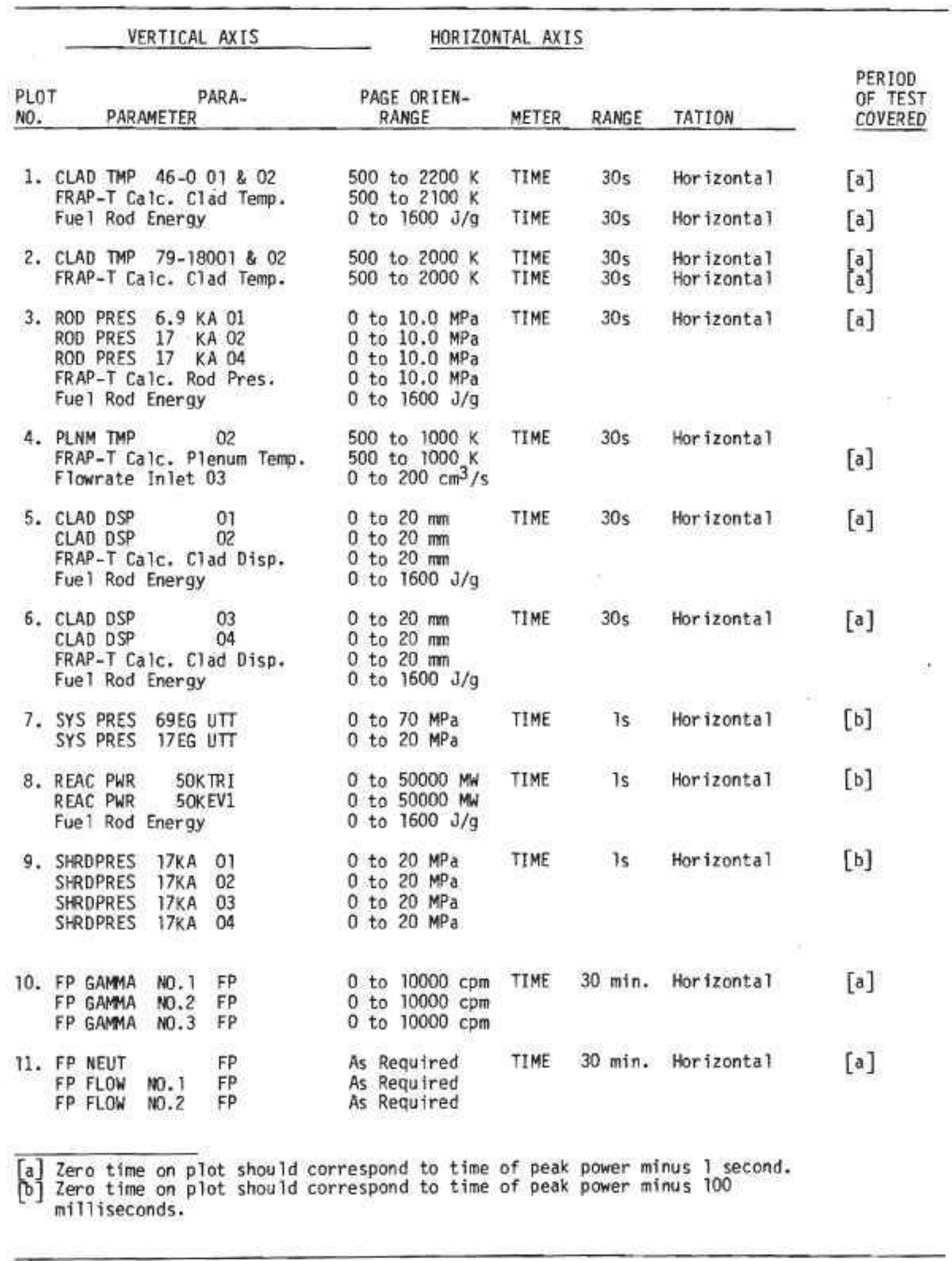


yfeld the log of the neutron-induced current SPND output. These data should be converted back to the actual currents and processed through the SPORT Program.

4.2.2 Experiment Data Report. Data plots presented in the Test RIA 1-2 Experiment Data Report will be used by Experiment Specification and Analysis personnel in analyzing the test performance. Plots of cladding surface temperature, fuel rod internal pressure, plenum temperature, cladding axial strain and fuel rod energy deposition versus time should be included for the transient.

4.2.3 Test Results Report. The initial data reduction requirements for the Test Results Report are given in Tables XI and XII. Comparison plots of posttest FRAP-T calculations with experimental data as a function of fuel rod power will be required for the steady state portions of the test. Comparison plots of FRAP-T calculations with experimental data as a function of time during the transient will be required. The calculated energy deposition for each fuel rod as derived from the SPNDs shall also be plotted. All plots will be 1/2-page size - horizontal orientation. Further data reduction requirements for the Test Results Report are expected to evolve during the analysis of the test data. These requirements will be transmitted to the data system group as the need arises. 
TABLE XI

PLOTS FOR RIA 1 -2 TEST RESULTS RESPORT - POWER CALIBRATION AND CONDITIONING PHASES

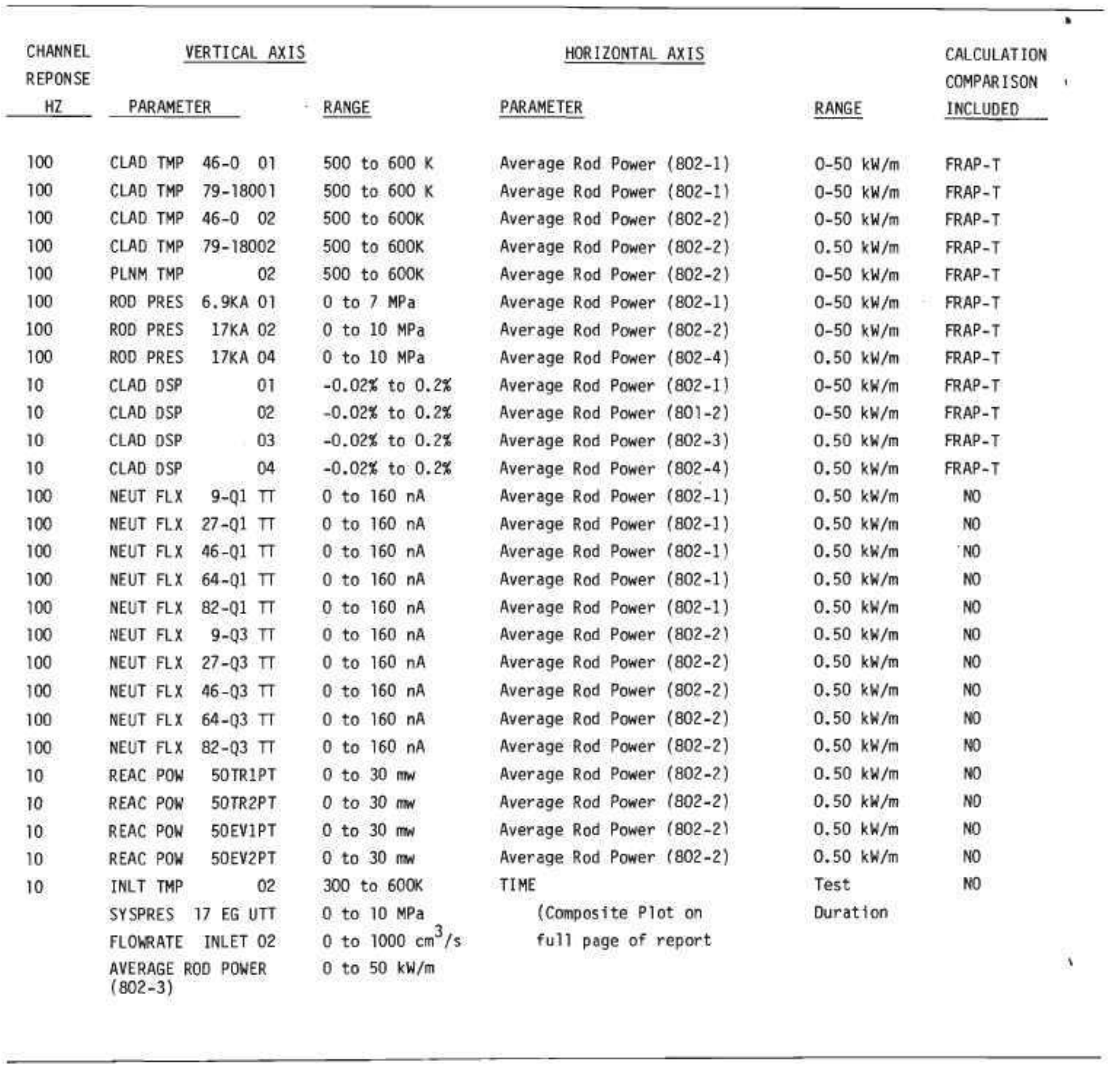


TABLE XII

PLOTS FAR RIA 1-2 TEST RESULTS PEPORT -

TRANSIENT PHASE

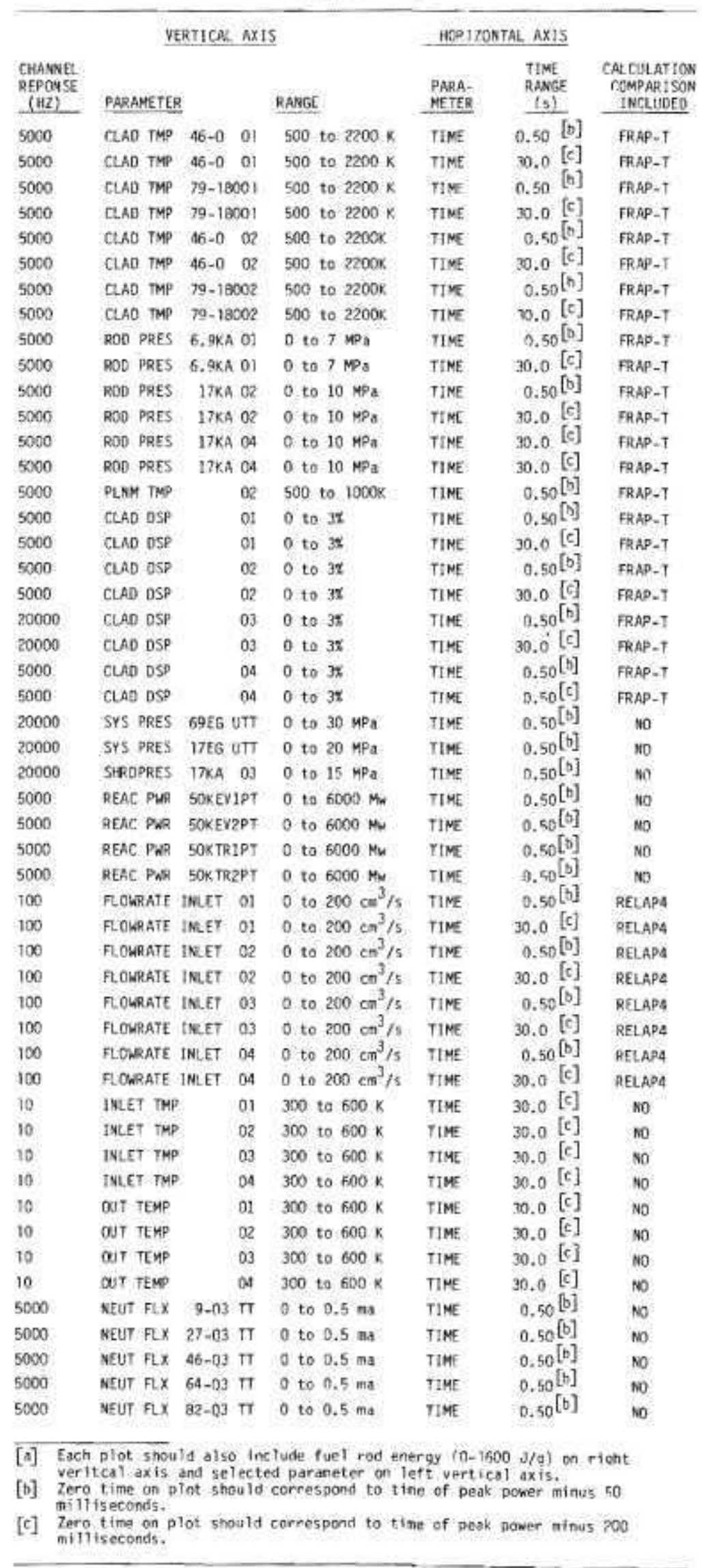




\section{POSTTEST OPERATIONS SUPPORT}

Before the test and following each cooldown, two loop water samples will be taken for chemical and fission product analysis. One sample should be analyzed for nitrogen, oxygen, and hydrogen and the other sent to the TRA counting laboratory for fission product and uranium analysis.

Table XIII lists the fission product inventory and the total activity $(\mathrm{R} / \mathrm{hr})$ at $30.5 \mathrm{~cm}$ distance, in air, from the fuel rods at various times after nuclear operation. Scheduling of the disassembly of the test train in the canal will depend on worker safety limits and the data in Table XIII. The calculations presented are based on expected power operation. Deviations between the planned and actual power histories may require recalculation of the activity levels and fission product inventories. The TRA hot cell has a current acceptance limit of $10^{-2}$ curies of $I^{131}$ per fuel rod. Efforts are being made to increase this limit. According to Table XIII, intact fuel rods can be shipped within 84 days after the final shutdown of Test RIA 1-2. They should be shipped as soon as possible. Fuel rods that fail during testing may be shipped within one week after the test is completed.

It is anticipated that the fuel rod cladding will be heavily oxidized and in an embrittled condition. Therefore, posttest handling, shipment, and storage should be performed as carefully as possible to minimize further fuel rod damage. Disassembly should be performed with the test train in a vertical position, if possible.

The cladding thermocouple and internal pressure transducer leads should be cut about 25 to $50 \mathrm{~mm}$ above the upper end plug. The plenum thermocouple leads should be cut 25 to $50 \mathrm{~mm}$ above the gas seal in each lead.

Closure plugs should be installed on the upper and lower ends of each flow shroud after removal from the test assembly to prevent 
TABLE XIII

RAOIOLOGICAL PARAMETERS APPLICABLE TO ONE RIA 1-2 ROO AFTER PBF TESTING[3]

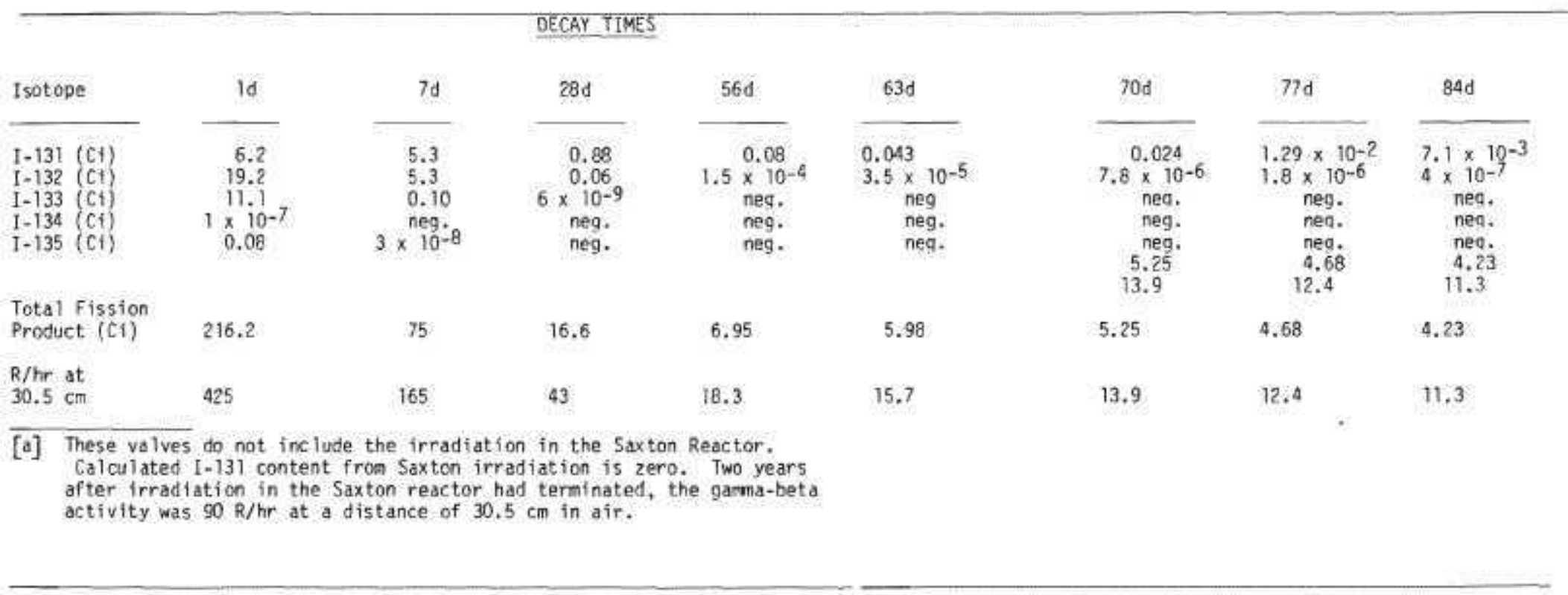


further loss of material from failed fuel rods during handling and shipment to the hot cell. 


\section{PIE REOUIREMENTS}

The flow shrouds for Rods $802-1,802-2,802-3$ and $802-4$ should be split into two pieces to facilitate fuel rod removal. Care should be taken to retain a 11 fuel particles during disassembly. The planned postirradiation examination (PIE) for Test RIA 1-2 consists of the following:

(1) A gamma scan and nvt determination of the $0.51 \%$ cobalt 99.49\% aluminum flux wires and the $100 \%$ cobalt flux wires for Rods 802-1 through 802-4. Each wire will be tagged to ident ify Test No., fuel rod number, test phase, and bottom end of wire.

(2) A garma scan of and nvt determination the $100 \%$ cobalt flux wires inserted in the core region. Each flux wire will be cut to $1.22 \mathrm{~m}$ length. Each flux wire will be tagged to identify Test No., irradiation time, and bottom end of wire.

(3) The visua 1, dimensional, and photographic examination of Rods 801-1 through $801-4$. All remaining fragments of failed fue 1 rods should be weighed for each rod.

(4) A leak check of all rods if cladding fallure is not obvious.

(5) The posttest measurement of the void volume and internal gas pressure and gas analys is of Rods $802-1,802-2,802-3$, and 802-4 if cladding failure did not occur.

(6) A spectral garma scan of Rod $802-3$.

(7) The neutron radiography of Rods $802-1,802-2,802-3$, and $802-4$.

(8) The preparation of twenty metallurgical mounts from Rods $802-1,802-2,802-3$, and $802-4$. The location of each of the 
metallurgical samples will be specified after posttest visual and photographic examination is completed.

(9) The preparation of two samples for scanning electron microscope (SEM) examination (one each from two rods to be specified later).

(10) The analysis and documentation of fue 1 and cladding structure and estimation of maximum temperatures for each metallurgical sample.

(11) The analysis and documentation of SEM examination of cladding fracture surface.

(12) A special examination including one microprobe sample and four cladding gas samples. 


\section{REFERENCES}

1. L. B. Thompson, D. L. Hagrman, P. E. MacDonald, Light-Water Reactor Fuel Behavior Program Description: RIA Fuel Behavior Experiment Requirements, RE-S-76-187 (October 1976).

2. Z. R. Martinson, RIA 1-1 Experiment Specification Document, TFBP-TR-202 (June 1977). 
C. M. Allison

R. W. Barber (DOE)

R. L. Benedett $i$

R. J. Buck 1 and

T. F. Cook

J. G. Crocker

B. R. DaBel1

G. H. Dechman

C. 0. Doucette

R. J. Drake

A. M. Eaton

E. E. Felix

S. R. Gossmann

$W$. R. George

R. N. Hagen

J. C. Haire

R. R. Hobbins, Jr.

T. Inabe (2)

A. M. Jensen

W. V. Johnston (NRC)

J. E. Koch

M. M. Larson

B. H. Little (DOE)

P. E. MacDonald

R. K. McCarde 11

Z. R. Martinson (15)

R. W. Marsha 11, Jr.

F. A. Meichle

A. S. Mehner

E. V. Mobley

M. N. Monson

W. P. Polkinghorn

W. J. Quapp

D. J. Schmutz

G. L. Schulz

A. J. Scott

R. S. Semken

L. A. Stephan

F. E. Stoll

P. 0. Strom (NRC)

R. H. Smith

R. E. Tiller (DOE) (3)

R. D. Ulrich

R. VanHouten (NRC)

J. 0. Zane

H. J. Zeile 
v 
APPENDIX A

\section{STATUS CHECK LISTS FOR INSTRUMENTATION}

The check lists provided in this appendix are to be incorporated in the RIA 1-2 Experiment Operating Procedure. 


\section{INSTRUMENT STATUS CHECKS}

Check List No. 1

TRA Assembly Area

This check list is found in "Instrument Check Procedure", TR-RIA-1201.

Check List No. $?$

Pre-In-pile Tube Loading

This check list is found in "Instrument Checkout Procedure", TP-RIA-1202. 
HEATUP INSTRUMENT STATUS

Check List No. 3

\begin{tabular}{|c|c|c|c|c|c|c|c|}
\hline \multirow{2}{*}{\multicolumn{2}{|c|}{$\begin{array}{l}\text { Instrument } \\
\text { Identifier }\end{array}$}} & $\begin{array}{l}\text { tor Pow } \\
\text { iPT C } \\
\text { erature } \\
\text { e Gauge } \\
\text { ad Flow }\end{array}$ & $\begin{array}{l}\text { Wer } \\
\text { Coolant } \\
\text { N Rate }\end{array}$ & $\begin{array}{r}-0.0 \\
450 \\
\text { re } 3.45 \pm \\
500 \pm 15\end{array}$ & $\begin{array}{l}\mathrm{MN} \\
\mathrm{K} \\
0.14 \mathrm{MPa} \\
\mathrm{cm}^{3} / \mathrm{s}\end{array}$ & \multicolumn{2}{|c|}{ 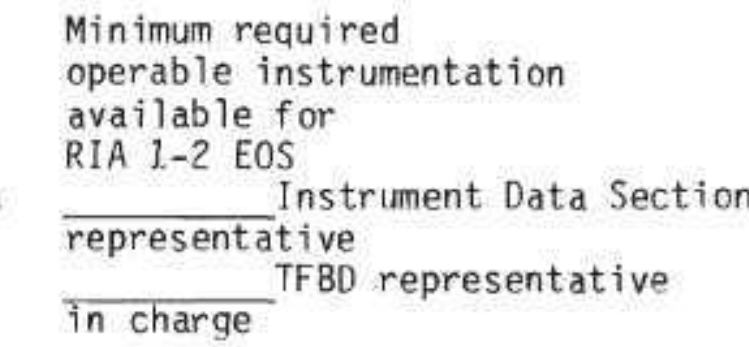 } \\
\hline & & & & $\begin{array}{l}\text { PBF/DARS } \\
\text { Reading }\end{array}$ & & $\begin{array}{l}\text { Required } \\
\text { Range }\end{array}$ & $\begin{array}{l}\text { Certification } \\
\text { Instrument is } \\
\text { within Range [a] }\end{array}$ \\
\hline CLAD & TMP & $46-0$ & 01 & & - & 430 to $470 \mathrm{~K}$ & \\
\hline CLAD & TMP & $79-180$ & 001 & & K & 430 to $470 \mathrm{~K}$ & \\
\hline CLAD & TMP & $46-0$ & 02 & & K & 430 to $470 \mathrm{~K}$ & \\
\hline CLAD & TMP & $79-180$ & 003 & & K & 430 to $470 \mathrm{~K}$ & \\
\hline$R O D P$ & PRES & 6. OKA & 01 & & $\mathrm{MPa}$ & 0.0 to $1.0 \mathrm{MPa}$ & \\
\hline ROD P & PRES & $17 \mathrm{KA}$ & 02 & & $\mathrm{MPa}$ & 2.5 to $3.5 \mathrm{MPa}$ & \\
\hline ROD P & PRES & $37 \mathrm{KA}$ & 04 & & $\mathrm{MPa}$ & 2.5 to $3.5 \mathrm{MPa}$ & \\
\hline PLNM & TMP & & 02 & & K & 430 to $470 \mathrm{~K}$ & Not Required \\
\hline SYS P & PRES & 69EG U & UT & & $\mathrm{MPa}$ & $\pm 3.5 \mathrm{MPa}$ of $\mathrm{He}$ ise & \\
\hline SYS P & PRES & 17KA U & UTT & & $\mathrm{MPa}$ & $\pm 1 \mathrm{MPa}$ of Heise & \\
\hline SYS P & PRES & $17 \mathrm{SCHU}$ & UT & & $\mathrm{MPa}$ & \pm 1 MPaof He ise & \\
\hline FLOWR & RATE & INL.ET & 01 & & $\mathrm{~cm}^{3} / \mathrm{s}$ & $500 \pm 15 \mathrm{~cm}^{3} / \mathrm{s}$ & \\
\hline FLOWR & RATE & INLET & 02 & & $\mathrm{~cm}^{3} / \mathrm{s}$ & $500 \pm 15 \mathrm{~cm}^{3} / \mathrm{s}$ & \\
\hline FLOWR & RATE & INLET & 03 & & $\mathrm{~cm}^{3} / \mathrm{s}$ & $500 \pm 15 \mathrm{~cm}^{3} / \mathrm{s}$ & \\
\hline FLOWR & RATE & INLET & 04 & & $\mathrm{~cm}^{3} / \mathrm{s}$ & $500 \pm 15 \mathrm{~cm}^{3} / \mathrm{s}$ & \\
\hline CLAD & DSP & & 01 & & $\mathrm{~mm}$ & -6.4 to $-3.8 \pi m$ & \\
\hline CLAD & DSP & & 02 & & - & -6.4 to $-3.8 \mathrm{~mm}$ & \\
\hline CLAD & DSP & & 03 & & $-m$ & -6.4 to $-3.8 \mathrm{~mm}$ & \\
\hline CLAD & DSP & & 04 & & - & -6.4 to $-3.8 \mathrm{~mm}$ & \\
\hline INLT & TMP & & 01 & & K & 440 to $460 \mathrm{~K}$ & \\
\hline INLT & TMP & & 02 & & K & 440 to $460 \mathrm{~K}$ & \\
\hline INLT & TMP & & 03 & & K & 440 to $460 \mathrm{~K}$ & \\
\hline INLT & TMP & & 04 & & - K & 440 to $460 \mathrm{~K}$ & \\
\hline
\end{tabular}




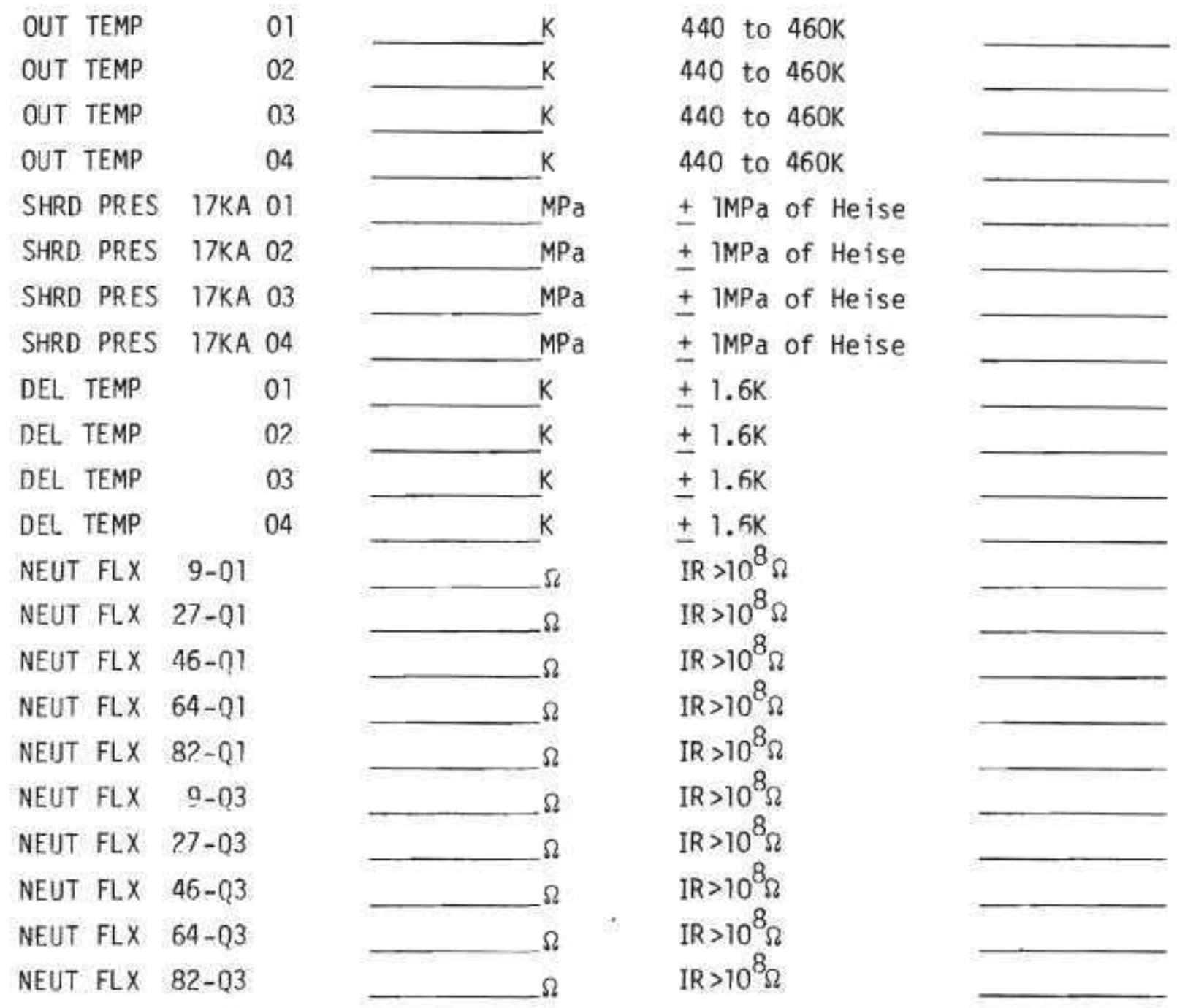

[a]This certification must be signed by the Supervisor of the Instrumentation and Data Section or his alternate. For instruments not within range the Supervisor of the Test Train Fabrication Section or his alternate must certify that the instrument is not functioning. For all cases where the instruments are not within range the RIA Project Leader's or his alternate's approval must be ohtained to continue the test procedures. 
PRE-POWER CALIBRATION INSTRUMENT STATUS

Check List No. 4

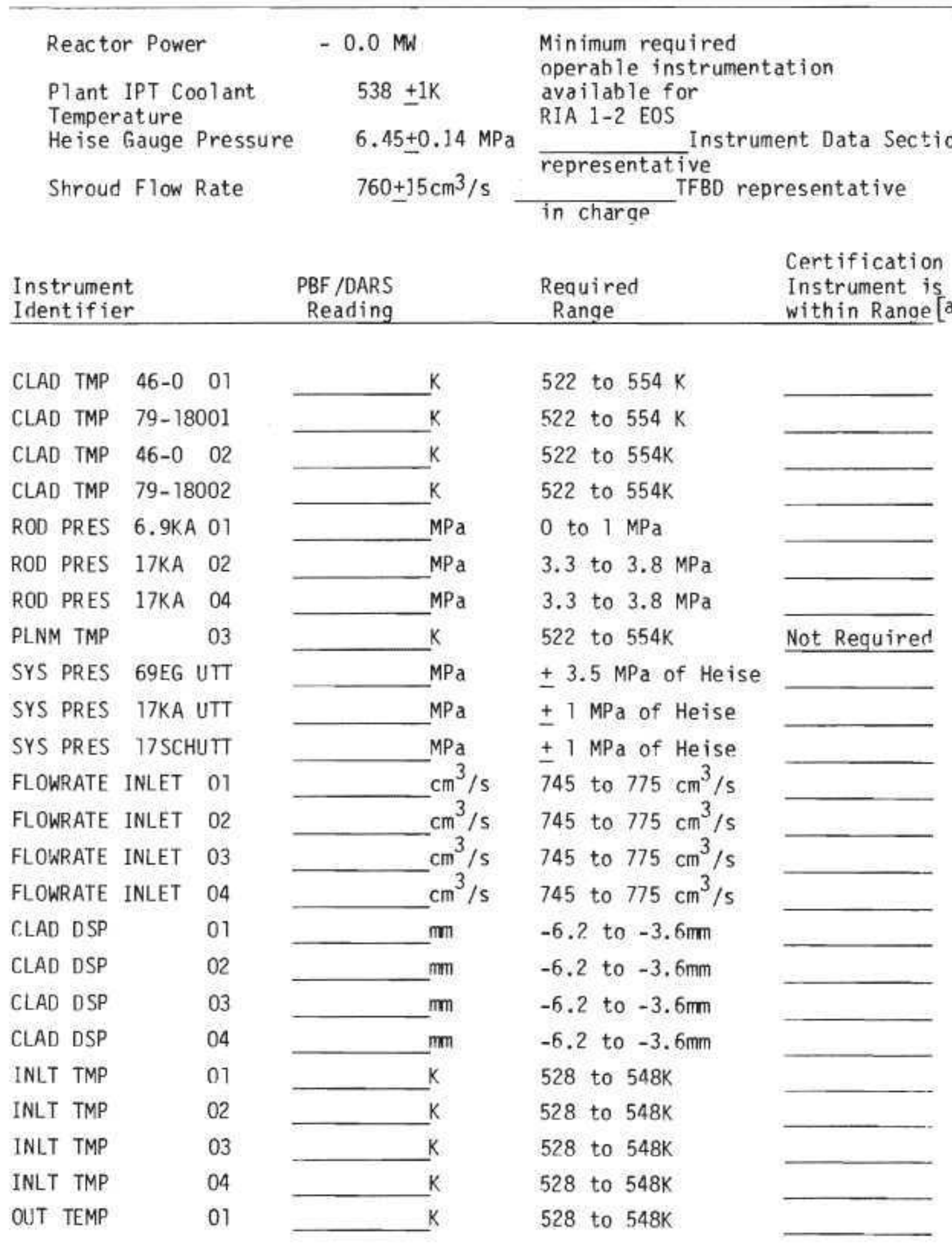




\begin{tabular}{|c|c|c|}
\hline OUT TEMP & $-K$ & 528 to $548 K$ \\
\hline OUT TEMP & K & 528 to $548 \mathrm{~K}$ \\
\hline OUT TEMP & K & 528 to $548 \mathrm{~K}$ \\
\hline SHRD PRES 17 KA 01 & $\mathrm{MPa}$ & $\pm 1 \mathrm{MPa}$ of Heise \\
\hline SHRD PRES $17 \mathrm{KA} 02$ & $\mathrm{MPa}$ & $\pm 1 \mathrm{MPa}$ of Heise \\
\hline SHRD PRES 17 KA 03 & $\mathrm{MPa}$ & $\pm 1 \mathrm{MPa}$ of Heise \\
\hline SHRD PRES 17 KA 04 & $\mathrm{MPa}$ & $\pm 1 \mathrm{MPa}$ of Heise \\
\hline DEL TEMP 01 & K & $\pm 1.6 \mathrm{~K}$ \\
\hline OEL TEMP 0 ? & K & $\pm 1.6 \mathrm{~K}$ \\
\hline DEL TEMP 03 & K & $\pm 1.6 \mathrm{~K}$ \\
\hline DEL TEMP 04 & K & $\pm 1.6 \mathrm{~K}$ \\
\hline NEUT FLX 9-Q1 & $-\Omega$ & IR $>10^{8} \Omega$ \\
\hline NEUT FLX $27-Q 1$ & $\Omega$ & \\
\hline NEUT FLX 46-Q1 & $-\Omega$ & IR $>10^{8} \Omega$ \\
\hline NEUT FLX 64-Q1 & $\Omega$ & \\
\hline NEUT FLX 82-Q1 & $\Omega$ & IR $>10^{8} \Omega$ \\
\hline NEUT FLX 9-Q3 & $-\Omega$ & IR $>10^{8} \Omega$ \\
\hline NEUT FLX 29-Q3 & $-\Omega$ & IR $>10^{8} \Omega$ \\
\hline NEUT FLX $46-Q 3$ & $-\Omega$ & IR $>10^{8} \Omega$ \\
\hline NEUT FLX $64-Q 3$ & $\Omega$ & IR $>10^{8} \Omega$ \\
\hline NEUT FLX 82-Q3 & $-\Omega$ & IR $>10^{8} \Omega$ \\
\hline
\end{tabular}

[a]This certification must be signed by the Supervisor of the Instrumentation and Data Section or $h$ is alternate. For instruments not within range the Supervisor of the Test Train Fabrication Section or his alternate must certify that the instrument is not functioning. For all cases where the instruments are not within range the RIA Projects Leader's or his alternate's approval must be obtained to continue the test procedures. 
PRE-TRANSIENT INSTRUMENT STATUS

Check List No. 5

\begin{tabular}{|c|c|c|c|}
\hline $\begin{array}{l}\text { Reactor Power } \\
\text { Plant IPT Coolant } \\
\text { Temperature } \\
\text { He ise Gauge Pressure } \\
\text { Shroud Flow Rate }\end{array}$ & $\begin{array}{l}-0.0 \mathrm{MN} \\
538 \pm \mathrm{K} \\
6.45 \pm 0.14 \mathrm{MPa} \\
760 \pm 15 \mathrm{~cm}^{3} / \mathrm{s}\end{array}$ & $\begin{array}{l}\text { Minimum required } \\
\text { operable instrumenta } \\
\text { available for } \\
\text { RIA 1-2 EOS Instrume } \\
\text { representative } \\
\text { in charge }\end{array}$ & $\begin{array}{l}\text { ation } \\
\text { ent Data Sectio } \\
\text { resentative }\end{array}$ \\
\hline $\begin{array}{l}\text { Instrument } \\
\text { Ident if ier }\end{array}$ & $\begin{array}{l}\text { PBF/DARS } \\
\text { Reading }\end{array}$ & $\begin{array}{l}\text { Required } \\
\text { Range }\end{array}$ & $\begin{array}{l}\text { Certification } \\
\text { Instrument is } \\
\text { within Range }\end{array}$ \\
\hline CLAD TMP 46-0 01 & K & 522 to $554 \mathrm{~K}$ & \\
\hline CLAD TMP 79-180 01 & $k$ & 522 to $554 \mathrm{~K}$ & \\
\hline CLAD TMP $46-003$ & K & 522 to $554 \mathrm{~K}$ & \\
\hline CLAD TMP $79-18003$ & K & 522 to $554 \mathrm{~K}$ & \\
\hline ROD PRES 6.9 KA 01 & $\mathrm{MPa}$ & 0 to $1 \mathrm{MPa}$ & \\
\hline ROD PRES 17 KA 02 & $\mathrm{MPa}$ & 3.3 to $3.8 \mathrm{MPa}$ & \\
\hline ROD PRES 17 KA 04 & $\mathrm{MPa}$ & 3.3 to $3.8 \mathrm{MPa}$ & \\
\hline PLNM TMP 03 & K & 522 to $554 \mathrm{~K}$ & Not Requirer \\
\hline SYS PRES 69 EG UTT & $\mathrm{MPa}$ & $\pm 3.5 \mathrm{MPa}$ of Heise & \\
\hline SYS PRES 17 KA UTT & $\mathrm{MPa}$ & $\pm 1 \mathrm{MPa}$ of Heise & \\
\hline SYS PRES 17 SCHUTT & $\mathrm{MPa}$ & $\pm 1 \mathrm{MPa}$ of Heise & \\
\hline FLOWRATE INLET 01 & $\mathrm{~cm}^{3} / \mathrm{s}$ & 745 to $775 \mathrm{~cm}^{3} / \mathrm{s}$ & \\
\hline FLOWRATE INLET 02 & $\mathrm{~cm}^{3} / \mathrm{s}$ & 745 to $775 \mathrm{~cm}^{3} / \mathrm{s}$ & \\
\hline FLOWRATE INLET 03 & $\mathrm{~cm}^{3} / \mathrm{s}$ & 745 to $775 \mathrm{~cm}^{3} / \mathrm{s}$ & \\
\hline FLOWRATE INLET 04 & $\mathrm{~cm}^{3} / \mathrm{s}$ & 745 to $775 \mathrm{~cm}^{3} / \mathrm{s}$ & \\
\hline CLAD DSP 01 & -mm & -6.2 to $-3.6 \mathrm{~mm}$ & \\
\hline CLAD DSP 02 & - & -6.2 to $-3.6 \mathrm{~mm}$ & \\
\hline CLAD DSP 03 & -mm & -6.2 to $-3.6 \mathrm{~mm}$ & \\
\hline CLAD DSP 04 & - & -6.2 to $-3.6 \mathrm{~mm}$ & \\
\hline INLT TMP 01 & K & 528 to $548 \mathrm{~K}$ & \\
\hline INLT TMP 02 & K & 528 to $548 \mathrm{~K}$ & \\
\hline INLT TMP 03 & K & 528 to $548 \mathrm{~K}$ & \\
\hline INLT TMP 04 & K & 528 to $548 \mathrm{~K}$ & \\
\hline OUT TEMP 01 & k & 528 to $548 \mathrm{~K}$ & \\
\hline
\end{tabular}




\begin{tabular}{|c|c|c|c|}
\hline OUT TEMP 02 & $Z^{k}$ & & 528 to $548 \mathrm{~K}$ \\
\hline OUT TEMP 03 & K & & 528 to $548 \mathrm{~K}$ \\
\hline OUT TEMP 04 & K & & 528 to $548 \mathrm{~K}$ \\
\hline SHRD PRES 17 KA 01 & $\mathrm{MPa}$ & & $\pm 1 \mathrm{MPa}$ of Heise \\
\hline SHRD PRES 17 KA 02 & $\mathrm{MPa}$ & & $\pm 1 \mathrm{MPa}$ of Heise \\
\hline SHRD PRES 17 KA 03 & $\mathrm{MPa}$ & & $\pm 1 \mathrm{MPa}$ of Heise \\
\hline SHRD PRES 17 KA 04 & $\mathrm{MPa}$ & & $\pm 1 \mathrm{MPa}$ of Heise \\
\hline DEL TEMP 01 & $Z^{k}$ & & $\pm 1.6 \mathrm{~K}$ \\
\hline DEL TEMP 02 & K & & $\pm 1.6 \mathrm{~K}$ \\
\hline DEL TEMP 03 & K & & $\pm 1.6 \mathrm{~K}$ \\
\hline DEL TEMP 04 & K & - & $\pm 1.6 \mathrm{~K}$ \\
\hline NEUT FLX 9-Q1 & $-\Omega$ & & IR $>10^{8} \Omega$ \\
\hline NEUT FLX 27-01 & $-\Omega$ & & IR $>10^{8} \Omega$ \\
\hline NEUT FLX $46-01$ & $-\Omega$ & & IR $>10^{8} \Omega$ \\
\hline NEUT FLX $\quad 64-Q 1$ & $\Omega$ & & IR $>10^{8} \Omega$ \\
\hline NEUT FLX 82-Q1 & $-\Omega$ & & IR $>10^{8} \Omega$ \\
\hline NEUT FLX 9-Q3 & $\Omega$ & & $\operatorname{IR}>10^{8} \Omega$ \\
\hline NEUT FLX 29-03 & $\Omega$ & & IR $>10^{8} \Omega$ \\
\hline NEUT FLX $46-Q 3$ & $-\Omega$ & & IR $>10^{8} \Omega$ \\
\hline NEUT FLX $64-Q 3$ & $-\Omega$ & & IR $>10^{8} \Omega$ \\
\hline NEUT FLX $82-03$ & $\Omega$ & & IR $>10^{8} \Omega$ \\
\hline $\begin{array}{l}\text { Fission Product } \\
\text { Detection System }\end{array}$ & $\begin{array}{l}\text { Operable/not } \\
\text { operable }\end{array}$ & & Operable \\
\hline
\end{tabular}

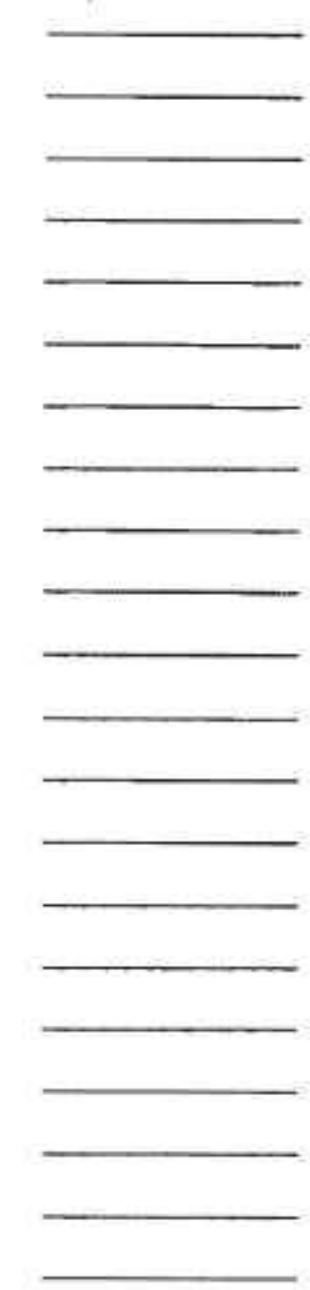

